\title{
The impact of parental employment trajectories on children's early adult education and employment trajectories in the Finnish Birth Cohort 1987
}

\author{
Pasi Haapakorva \\ pasi.haapakorva@thl.fi \\ Tiina Ristikari \\ Mika Gissler
}

\author{
The National Institute for Health and Welfare and University of Oulu, Finland \\ The National Institute for Health and Welfare, Finland \\ The National Institute for Health and Welfare and University of Turku, Finland, \\ Karolinska Institute, Sweden
}

(Received December 2016, Revised June 2017)

http://dx.doi.org/10.14301/Ilcs.v8i4.441

\section{Abstract}

The Finnish Birth Cohort 1987 grew up during the recession that hit Finland in the early 1990s, which had an impact on their parents' activity in the labour market. In this paper we use Finnish register data to build employment and education sequences for all young people born in Finland in 1987 for the period 2005-2012 and employment sequences for all their parents for the entire length of their children's lives from 1987 until 2012. The sequences were analysed and clustered, and four multinomial logistic regression models were used to find how parents' trajectories connect to their children's early adulthood trajectories. Most parents had been on a stable employment trajectory, but we found mothers and fathers who were absent from the labour market during the recession of the 1990s and after it - and some parents never entirely returned to work during this 1987-2012 follow-up. Likewise, most children were either on an employment or education trajectory, but we found groups of children who were on very early child care trajectories, unemployment trajectories, or on a trajectory with no records in the Finnish registers, which in the Finnish context implies that those young people are not employed, not in education and not receiving any of the various benefits. Disadvantageous trajectories were mostly very lasting. We found strong connections between parents' disadvantages in the labour market and children's disadvantageous early adulthood trajectories, even when adjusting for strong background variables. The strongest connections arise from parents' long absences from the labour market.

\section{Keywords}

Sequence analysis, unemployment, employment, education, life course, trajectory, birth cohort, education, recession, register data 


\section{Introduction}

Early adulthood is a period during which individuals begin to move into economic independence. In most industrialised countries, including Finland, this is a period when most further education or labour market entry takes place. This period and the transitions that it involves during youth are impacted by the children's family's educational background (Witting \& Keski-Petäjä, 2016). Disadvantageous early adulthood transitions may have their roots in childhood (Caspi, Wright, Mofitt \& Silva, 1998) and we know that family background, including parents' educational level and socioeconomic status, continues to have a strong influence in early adulthood regardless of children's educational level (e.g. Barone \& Schizzerotto, 2011; Bukodi \& Goldthorpe, 2011; Härkönen \& Bihagen, 2011; Mastekaasa, 2011; Sirniö, Kauppinen \& Marttinen, 2016).

When thinking of mechanisms for how family background affects later life, we take a broad viewpoint, using life course theory (Elder, Johnson \& Crosnoe, 2003), which states that individuals make choices in the historical and cultural circumstances in which they find themselves at the time. During childhood, parents create much of those circumstances. Parental poverty (Bäckman and Nilsson, 2011) and unemployment (Gray \& Baxter, 2012; Rege, Telle \& Votruba, 2007) could affect children's school achievement and later labour market integration. On the other hand, parental unemployment can also raise children's educational aspirations, as children come to recognise the value of higher education (Schoon, 2014), and during hardship, a high parental educational level also fosters children's aspirations (Mortimer, Zhang, Husseman \& Wu, 2014).

Previous research related to early adult trajectories-sometimes referred to as school-towork transitions-has established that in addition to parental educational attainment, several other family-related structural variables, such as poverty and socioeconomic status, have an impact, either directly or indirectly, on these transitions. Previous research has also established connections between several individual characteristics, such as sex and school achievement (Brzinsky-Fay, 2015; Larja et al, 2016; Ristikari et al., 2016; Schoon, 2014). What is less clear is how parental labour market activities impact early adulthood trajectories above and beyond the impact of parental education and other known background variables. No study that we are aware of has measured parental labour market activity longitudinally.

In this study we see early adulthood as a social sequence, which contains ordered set of states (Cornwell, 2015). By analysing the sequences (sequence analysis) we are able to see the transitions holistically and in all their diversity, and look for structure in the mass of information (Brzinsky-Fay, 2011; Schoon \& Lyons-Amos, 2016). Many researchers have successfully utilized sequence analysis in the study of school-to-work transitions and life course research in general (Brzinsky-Fay, 2007; Brzinsky-Fay, 2015; BrzinskyFay \& Solga, 2016; Ilmakunnas, Kauppinen \& Kestilä, 2015; McVicar \& Anyadike-Danes, 2002; Sackmann \& Wingens, 2003).

\section{The Finnish context for early adulthood employment and education trajectories}

In Finland, comprehensive school achievement strongly shapes future educational paths. Comprehensive school ends at age 15-16, when most young people make a choice between two types of upper-secondary-level education: uppersecondary-level vocational education and general upper-secondary-level education. The former most often requires significantly lower comprehensive school achievement than the latter, while the latter much more often leads to academic education. In the Finnish Birth Cohort 1987 (FBC 1987), previous research shows that children with a high parental level of education are much more likely to attain a post-compulsory degree than children whose parents have only a comprehensive level education. Parental level of education, along with child's sex, is strongly linked to children's achievement in compulsory school (Ristikari et al., 2016).

Labour markets have changed across cohorts, affecting young people's transition to work. Early employment trajectories have not been simple pathways for some time. Cyclical economic turns, involving downswings and upswings, affected young people entering the labour market already in the 1990s (Gangl, 2002; Zwysen, 2014). At the same time, labour market entry is a major determinant of later labour market integration. Those who enter as unemployed are more likely to become unemployed later (Steijn, Need \& Gesthuizen, 2006). In Sweden, those who entered the labour 
market during the economic recessions of the mid1970 s and the early 1990s have suffered long-term deficits in career progression (Härkönen \& Bihagen, 2011). Mroz and Savage (2006) have shown with US data that youth unemployment causes a catch-up response, increasing the likelihood of training to mitigate the setbacks, but young people do not fully recover from the effects of unemployment. In Finland, during the recessions of the early 1990s and the late 2000s, the employment levels of those aged 15-24 and 25-34 fell more steeply than those of people older than 35 . In fact, the only age group in Finland with a positive employment curve during the period 2008-2015 was those aged 55-64 years (Official Statistics Finland: Labour Force Survey, 2015). The latest "Great Recession" (Kangas \& Saloniemi, 2013) likely impacted the FBC 1987.

\section{Long-term changes in the Finnish labour market for parents}

Long-term changes in the Finnish labour market have been affecting the FBC 1987 parents, whose earliest employment records go back to the 1940s. According to a review by Kangas and Saloniemi (2013) on the history, current situation, and future of the Nordic model in Finland, a number of issues are of great relevance here. First, the structural transformation of the economy in Finland has been late but rapid. Agricultural labour remained important for several decades longer than in other Nordic countries. Primary production was the dominant labour branch up until the late-1950s, but was in strong decline after the 1940s, making up a quarter of the economy in 1970, 14 percent in 1980, and down to $6 \%$ in 2000 and $4 \%$ in 2012. The decline affected both sexes. The decline in manufacturing jobs, however, was steeper among women than men: the number of women working in manufacturing more than halved in the period 1980-2012, while men dropped by a fifth. Meanwhile the tertiary sector has seen steady growth, with women having a two-thirds majority since the 1970s. The decline in primary production and manufacturing and the growth of the tertiary sector has strongly affected labour force demand by sex and educational level.

Second, the economic depression of the 1990s hit Finland the hardest among the Nordic countries. GDP saw three negative years after stagnation in 1990 and unemployment rose from $3 \%$ to $16 \%$. At the end of the millennium, due in part to the structural transformation of the Finnish labour market, Finland faced simultaneously both unemployment and a labour shortage due to skills mismatch. Male dominant branches were hit hardest and women found it easier to find new jobs in the service sector; the same pattern was also true in the 2008 economic crisis. In 2008, the employment rates declined among all men, recovering in the following year for all but those with only a comprehensive education (Kangas \& Saloniemi, 2013). These two factors combined, late but rapid decline in traditional sectors followed by skills mismatch, have likely led to a disappearance of job opportunities for the FBC 1987 parents.

\section{Objectives}

Our first objective is to identify the most significant early adult trajectories in an entire Finnish birth cohort born in 1987, using rich sequential register data, with sequence analysis and clustering methods. Due to register data availability and completeness (in terms of events relating to moving into adulthood and the length of the FBC 1987 follow-up at present), we limit our study of early adulthood to 18-25 years of age (2005-2012). We expect to find many youth still in education in 2012, but many have already taken up employment after finishing upper-secondary-level vocational school at 19 years of age. We are paying close attention to those young adults who have not had much or any post-compulsory education or employment history. One of the strengths of register data is that we always at least know what people are not doing.

The second objective is to identify parents' most common employment trajectories during the lives of their children born in 1987, following them up to 2012, a period of 26 years, using equally rich register data and sequence analysis methods. We are not considering the parents' age, although we will know if they have retired or are deceased.

What we also seek to explore, and which is our third objective, is how much the children's early trajectories are affected by their parents' employment trajectories. We will look at how unemployment and activities outside the labour market at distinct times affect children, while controlling for parents' education and marital status, children's sex, residence abroad and comprehensive school achievement. We include residence data to explain some missing register 
data. The next section will cover the data and methods, the third section will present the results, and the fourth section includes a discussion.

\section{Data and methods}

The Finnish Birth Cohort 1987 ( $N=59$ 476) includes data from several registers from both children born in 1987 and their parents. In Table 1 we present the data we have included in the analyses for this paper. All the mothers are present in the data, but 821 children had no registered father. In total, we analyse trajectories for 177,604 individuals. The Finnish Birth Cohort 1987 (Paananen \& Gissler, 2011; Ristikari et al, 2016) consists of data from several register holders. In this study, the data on employment, pensions and benefits are from the Finnish Centre for Pension (ETK), and we have added study grant data from the Social Insurance Institution of Finland (Kela), unemployment data from the Finnish Ministry of Economic Affairs and Employment, and finally social assistance data from the Finnish National Institute of Health and Welfare (THL). All linkages were done by using parents' and children's personal identity codes available in all Finnish registers.

For the sequence analysis, we studied the labour market statuses for 96 months for the children, in the period 2005-2012, and 52 half-year periods for their parents, for the period 1987-2012. The children's data are characterised by a substantial number of brief periods of employment or benefit periods, as short-term employment is common during education among young adults. For the children, we look at cumulative periods of at least 10 days per month and for the parents we account for all the cumulative periods with a length of at least one month. It is common to find many overlapping statuses for the study periods, which compelled us to prioritize. Above all others was death, and we prioritised benefit periods that commonly occur during periods of employment, education, and entrepreneurship. Unemployment, different types of pensions and social assistance come last. An employed person receiving a study grant is considered studying, likewise an employed person receiving childcare or sickness benefits is not considered employed (a person receiving a parental or sick leave benefit has their wage suspended but they are allowed to return to their job after the benefit period). However an employed person is never considered unemployed or drawing a pension, but pensions and unemployment benefits are considered over social assistance. A majority of parents' benefit data are not available in the FBC 1987 from 1994 to 2004, but employment and pension data are complete. Data availability improves in 2005, when a new benefit register at Centre for Pensions was formed.

The status "missing" is meaningful in this study. In the sequence analysis, we handle it like all other statuses. Children's missing status denotes not being in employment, education or in receipt of any of the many benefits. The same is true for parents, except for the period before 2005 where only data on employment and pensions are available.

In the analyses, we employ several background variables. We use children's sex, comprehensive school achievement and in part, their residence history for residence abroad to account for some of the missing data. We measure parents' marriage when their children were age 22 (2010) and educational level at children's age 21 (2009). Education is measured in four levels: comprehensive (compulsory education only), upper-secondary (general upper-secondary-level or vocational education), lower academic (community/junior college level, "opistoaste", obsolete but common among parents) and higher academic level (bachelor's and above). 
Table 1: Data sources for the sequence analysis and the regression analyses

\section{Register holder}

Centre for Pensions
Ministry of Economic Affairs and Employment

The Social Insurance Institution of Finland

National Institute of Health and Welfare

Statistics Finland

Population Register Centre

The Finnish National Board of Education
Data

Employment

Entrepreneurship

Alternation leave

Child care (all)

Sickness benefit

Accident benefit

Rehabilitation

Unemployment benefit

Old age pension

Disability pension

Other pension

Unemployment periods

Study grant

Unemployment benefit

Child care (parental leave)

Social assistance

Identity number (sex)

Educational level

Date of death

Place of residence

Marriages and divorces

Identity number (sex)

Comprehensive school achievement
Availability

$-2012(c+p)$

$-2012(c+p)$

2005-2012 (c+p)

2005-2012 (c + p)

2005-2012 (c + p)

2005-2012 (c + p)

2005-2012 (c + p)

2005-2012 (p)

-2012 (p)

$-2012(c+p)$

$-2012(p)$

1999-2015 (c)

2005-2012 (c)

1987-1994 (p)

1987-1994 (p)

1988-2012 (c)

$1987(c+m)$

2008 (p)

$-2012(c+p)$

1987-2012 (c)

-2012 (p)

1987 (f)

2003- (c)

$\mathrm{c}=$ child, $\mathrm{p}=$ parents, $\mathrm{m}=$ mother, $\mathrm{f}=$ father

Availability of data from different registers varies, and for the parents a majority of the benefit data are not available in the FBC 1987 from 1994 to 2005.

The data on comprehensive school achievement (average of all awarded grades on a scale of four to 10 at the end of comprehensive school, Table 2) is derived from the children's applications for further education, and in $4.4 \%$ of the cases, it is missing due to one of two reasons: they have applied earlier than average, for which we do not have data, or they have never applied, at least not through the centralized system. Of those $4.4 \%$ with missing achievement records, $46 \%$ have obtained a postcomprehensive degree by the end of 2012 . We use multiple imputations (10 imputations, 20 iterations, predictive mean matching) using the 'mice' package (Van Buuren \& Groothuis-Oudshoorn, 2011) in R (R Core Team, 2015) to account for the missing data. We have included all the variables present in the regression models along with the degree data in the imputation model to achieve the strongest possible imputation results. We did not impute achievement records for those who had died. 
Table 2: Children's comprehensive school achievement* by sex

\begin{tabular}{rcccc} 
& $\mathrm{n}$ & mean & SE & missing \\
\hline Female & 27,775 & 8.07 & 0.006 & 1,266 \\
Male & 29,084 & 7.49 & 0.006 & 1,351 \\
Total & 56,859 & 7.77 & 0.004 & 2,617 \\
\hline
\end{tabular}

* Average of all awarded grades at the end of comprehensive school. Scale 4-10.

Some children have no registered father, and some have confidential residence histories, for example, due to their occupation, status, or threats to themselves or to their family. We have accounted for missing data by adding a category for the missing data.

For the distance matrix in sequence analysis, we use the hamming distance method with a substitution cost of 1 , and for clustering we use the Ward method along with the non-hierarchical PAM method (Studer, 2013). The children's data are split into two due to large size, so we have created a set of clusters from both and matched them cluster-tocluster to create a whole data set (see Appendix for more information about the cluster analysis). For the children, we chose a solution with 12 clusters, including one for deceased persons and another for the ones with no or little data. The mothers' data were split into seven clusters, which included five clusters between steady career and death, and for the fathers, 10 clusters were sufficient to capture most of the variance.

To examine the relationship between parents' and children's trajectories we use multinomial logistic regression. The exponentiated coefficients are relative risk ratios (RRR). We have included both parents' clusters in the model as independent variables along with control variables. We will present four regression models. The first model includes only the parents' trajectories as independent variables. In the second model we add parents' highest level of education, in the third model we add children's sex, residence abroad, and parents' marital status, and finally in the fourth model we add the children's average grade at the end of comprehensive school. The results in the fourth model are pooled from the imputed datasets. Due to the multiple imputations, those children who had died before the end of 2012 were left out of all the models. We do not account for a possible sibling effect in the models, because only one per cent of the cohort share a parent, and our data include no data on children born in other years.

\section{Results \\ Cluster results}

Two sets of results are presented here. First, we take a brief look at the data, next a look at the sets of clusters we have created from the children's (C indicating children) and their parents' ( $M$ indicating mother, $\mathrm{F}$ for father) data, and finally, we present the results of the multinomial logistic regressions.

Finnish young people stay in school for a relatively long time. Compulsory school ends at age 16 , but most attend non-compulsory uppersecondary-level school immediately after, which usually lasts for three years. At this point it is common to take a gap year. The Finnish Birth Cohort 1987 finished their upper-secondary-level degrees in spring 2006. A year after, in May 2007, $34 \%$ of cohort members had no data in these registers, meaning they were not in employment, education or on any of the many benefits. Another year later, $14 \%$ remained in the no-data group and in 2009 some $10 \%$ remained. The share of 'no-data' settles down to about $8 \%$ at each cross-section.

At the other end of the series, in the beginning of $2012,29 \%$ of cohort members are on a study grant, down from $37 \%$ the year before. In 2009-2010 cohort members on a study grant peaks at $42 \%$. Meanwhile cross-section employment at the end of each year steadily rises to $53 \%$ in 2012 .

We have chosen a rather large set of clusters for our subjects, the children and their fathers and mothers. There are several reasons for this. First, our data set is relatively large, so less common trajectories can be separated into clusters. Second, as we show later in the results, the parent-children trajectory connections are far from random: we obtain stronger results with more clusters. In the parents' case, we use time-variance in the unemployment and pension clusters to identify the effect of parental labour-market inactivity at different times during the children's life-course, 
resulting in a few more clusters. Third, real-life trajectories are very complex, and with this data we are able to capture a few more of them than previously was possible.

Table 3: Children's cluster results by sex, C1-C12

\begin{tabular}{|c|c|c|c|c|c|c|}
\hline Group & Females & $\%$ & Males & $\%$ & Total & $\%$ \\
\hline C1. Education & 10,307 & 35.5 & 8,689 & 28.5 & 18,996 & 31.9 \\
\hline $\begin{array}{l}\text { C2. Education with secondary } \\
\text { level study grant }\end{array}$ & 5,308 & 18.3 & 3,316 & 10.9 & 8,624 & 14.5 \\
\hline C3. Employment & 2,418 & 8.3 & 7,030 & 23.1 & 9,448 & 15.9 \\
\hline $\begin{array}{l}\text { C4. Employment with } \\
\text { secondary level study grant }\end{array}$ & 2,314 & 8 & 4,077 & 13.4 & 6,391 & 10.7 \\
\hline $\begin{array}{l}\text { C5. Employment after } \\
\text { difficulties }\end{array}$ & 649 & 2.2 & 1,370 & 4.5 & 2,017 & 3.4 \\
\hline C6. Early child care & 2,548 & 8.8 & 16 & 0.1 & 2,564 & 4.3 \\
\hline $\begin{array}{l}\text { C7. Late child care via } \\
\text { employment or education }\end{array}$ & 2,321 & 8 & 347 & 1.1 & 2,668 & 4.5 \\
\hline $\begin{array}{l}\text { C8. Fragmented employment } \\
\text { / unemployment with } \\
\text { secondary level study grant }\end{array}$ & 327 & 1.1 & 900 & 3 & 1,227 & 2.1 \\
\hline $\begin{array}{l}\text { C9. Fragmented } \\
\text { unemployment / income } \\
\text { support }\end{array}$ & 363 & 1.2 & 796 & 2.6 & 1,159 & 1.9 \\
\hline $\begin{array}{l}\text { C10. Fragmented no data / } \\
\text { education / employment }\end{array}$ & 1,543 & 5.4 & 2,229 & 7.3 & 3,772 & 6.3 \\
\hline C11. Not much or no data & 745 & 2.6 & 1,259 & 4.1 & 2,004 & 3.4 \\
\hline C12. Deceased & 198 & 0.7 & 406 & 1.3 & 604 & 1 \\
\hline Total & 29,041 & 100 & 30,435 & 100 & 59,476 & 100 \\
\hline
\end{tabular}

In the children's clusters (Table 3, Figure 1 ) we find that it is necessary to keep some clusters split based on whether there is an upper-secondary-level study grant during 2005 and in the first half of 2006 or not. This benefit is granted based on parents' income. By keeping respondents with and without study grants separate we not only distinguish young people who are well off from those who are less well off in their youth; this distinction enables us to discern the paths of both groups more accurately.

The first four clusters include the main education and employment trajectories. Most children born in 1987 finish their upper-secondary-level education in spring 2006 and some will begin employment or education during the following months. However, it is common to take one or two gap years working, applying to schools, or in the military. Most males and some females spend at least half a year in the Finnish army, but this is not designated in our data.

After the education and employment clusters, we find a cluster in which the share of employed reaches $80 \%$ only at the end. We named this cluster C5 'employment after difficulties', since employment shows a steady rise up to late 2008, when the latest recession hit Finland, and declines, though it picks up again after a few years. Following that, based on the study period, we have early and late child care, clusters $\mathrm{C} 6$ and C7. It is worth noting that nearly a fifth of FBC 1987 females were on either of these trajectories ( $9 \%$ and $8 \%$ of females, respectively), but only $1 \%$ of males have spent considerable lengths of time receiving child care related benefits.

Clusters C8 to C11 include those with more NEET-type (Not in Education, Employment or 
Training) trajectories. In the eighth cluster, unemployment varies with employment, and in the ninth, with social assistance. In the 10th cluster, trajectories show variation between education, work, unemployment and a sizable share of no data which stays at around $30 \%$ during the second half. Individuals having little or no data at all, at least not in these registers, are clustered in the 11th cluster. The last one is reserved for the deceased. All these clusters have a male-majority.

We find children's NEET-type trajectories, the unemployment and the no-data trajectories, very stable over a period of five to eight years.

The mothers' (Table 4, Figure 2) and fathers' (Table 4, Figure 3) employment trajectories have been divided in much the same way. In the first place, we have those with continuous careers, while the last clusters are for the deceased. Between them we first have labour market inactivities of different timings and lengths, followed by pensions. In both series of clusters, before the deceased, we have a cluster of individuals having little or no data.
Both mothers and fathers show clear signs of the recession that hit Finland in the early 1990s. The fathers' data also show signs of the latest recession in 2008, while the mothers' data do not, consistent with its greater impact on male-dominated industries. The fathers' data are split into more clusters, 10 versus seven for mothers, since fathers have more complex pension trajectories than mothers, with two clusters for disability pension and an old age pension cluster, while more than twice as many fathers have died than mothers, resulting in deaths split into two clusters (early and late).

A prominent feature of the parents' clusters is the missing benefit data between the mid-1990s and the mid-2000s. While we cannot take a deeper look into unemployment during this period, we do have employment and pension data, which allows us to consider different lengths of labour market inactivities. 
Table 4. Parents' clusters, educational level, marital status, and children's residence abroad

\begin{tabular}{|c|c|c|}
\hline & $\%$ & $\mathrm{n}$ \\
\hline Mother M1: Employment or entrepreneurship) & 68.2 & 40,550 \\
\hline M2: Outside of labour market in the 90's & 16.7 & 9,928 \\
\hline M3: Long gap in labour market activity & 5.3 & 3,164 \\
\hline M4: Unemployed throughout & 2.6 & 1,526 \\
\hline M5: Disability pension & 2.5 & 1,490 \\
\hline M6: Not much or no data & 3.5 & 2,109 \\
\hline M7: Deceased & 1.2 & 709 \\
\hline Total & 100 & 59,476 \\
\hline Father F1: Employment or entrepreneurship) & 72.2 & 42,952 \\
\hline F2: Unemployed in the early $1990 \mathrm{~s}$ & 4.3 & 2,537 \\
\hline F3: Unemployed starting in 2009 & 3.2 & 1,879 \\
\hline F4: Unemployed after early 90's & 2.9 & 1,750 \\
\hline F5: Early disability pension & 2.7 & 1,594 \\
\hline F6: Late disability pension & 2.5 & 1,490 \\
\hline F7: Retirement pension after work & 3.2 & 1,928 \\
\hline F8: Not much or no data & 3.3 & 1,967 \\
\hline F9: Early death & 2.0 & 1,207 \\
\hline F10: Late death & 2.3 & 1,351 \\
\hline F11: No registered father & 1.4 & 821 \\
\hline Total & 100 & 59,476 \\
\hline Parents' education (2008): Higher academic level & 25.9 & 15,412 \\
\hline Comprehensive level & 6.9 & 4,128 \\
\hline Upper secondary level & 43.1 & 25,639 \\
\hline Lower academic level & 24.0 & 14,297 \\
\hline Total & 100 & 59,476 \\
\hline Parents' marriage (2009): Parents married & 57.8 & 34,352 \\
\hline Parents not married & 42.2 & 25,124 \\
\hline Total & 100 & 59,476 \\
\hline Residence abroad at any time: Never abroad & 95.0 & 56,531 \\
\hline Abroad at some point & 4.7 & 2,788 \\
\hline Residence history not available & 0.3 & 157 \\
\hline Total & 100 & 59,476 \\
\hline
\end{tabular}


C1. Education (31.9\%)

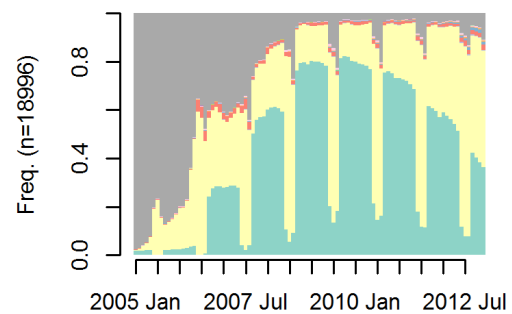

C4. Employment with secondary level study benefit $(10.7 \%)$

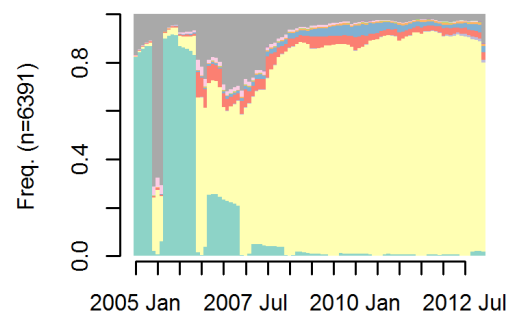

C7. Late child care via employment or education $(4.5 \%)$

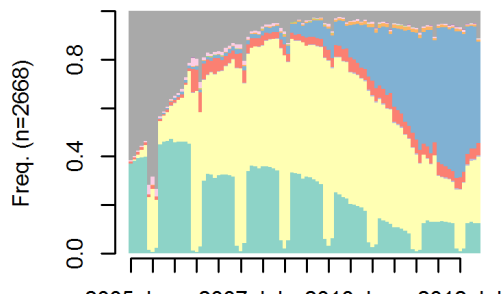

2005 Jan 2007 Jul 2010 Jan 2012 Jul

C10. Fragmented no data / education / employment $(6.3 \%)$

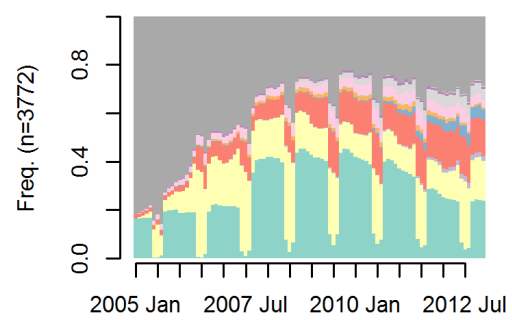

C2. Education with secondary level study benefit $(14.5 \%)$

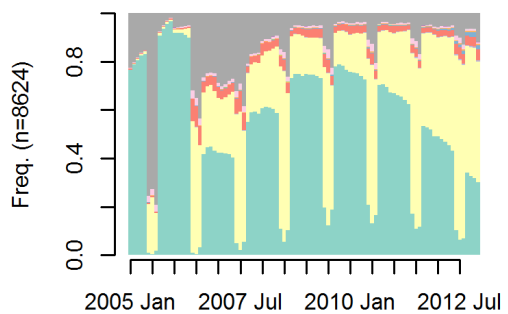

C5. Employment after difficulties (3.4\%

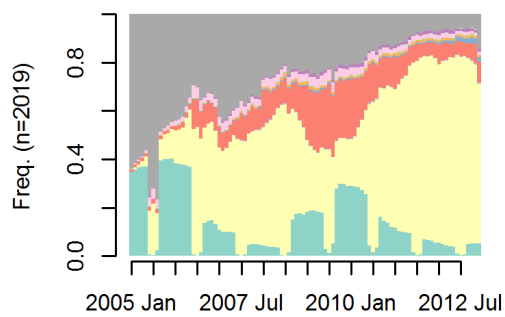

C8. Fragmented employment I unemployment with secondary Ivl study bnf (2.1\%)

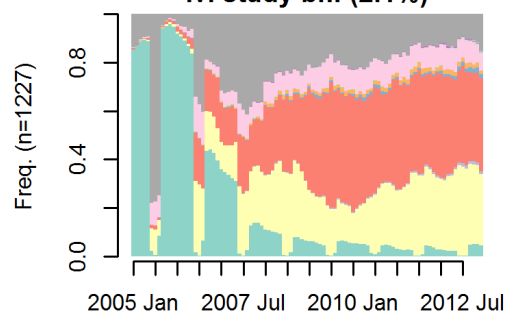

C11. Not much or no data $(3.4 \%)$

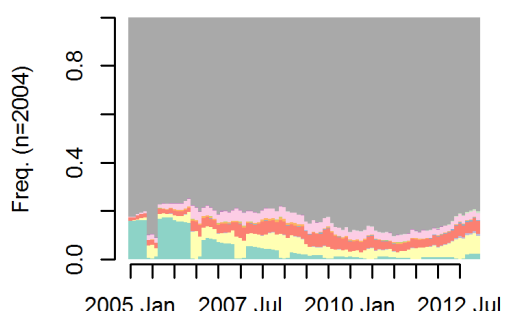

C3. Employment (15.9\%)

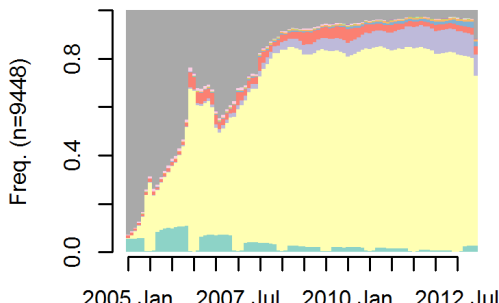

C6. Early child care $(4.3 \%)$

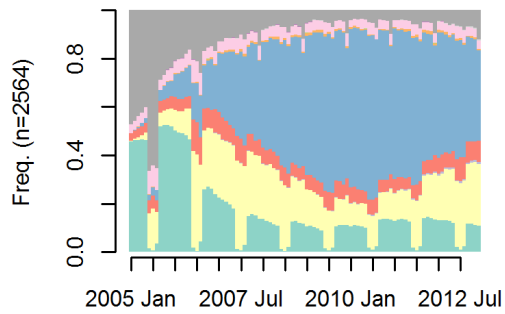

C9. Fragmented unemployment / social assistance $(1.9 \%)$

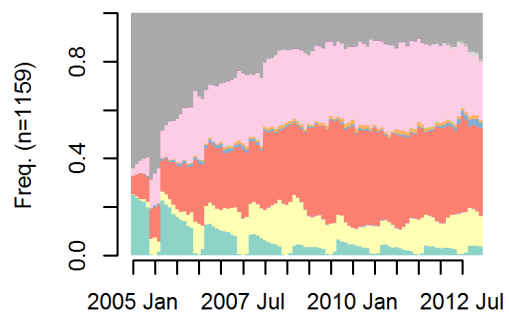

C12. Deceased (1\%)

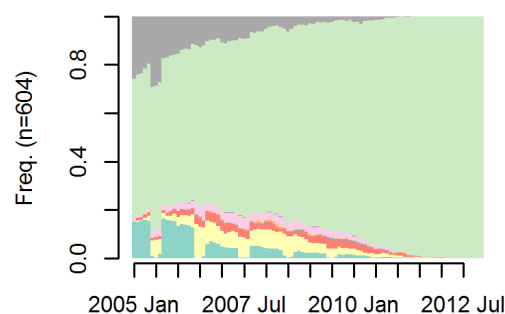

Figure 1. State distribution plot of children's clusters 
M1. Employment or entrepreneurship (68.2\%)

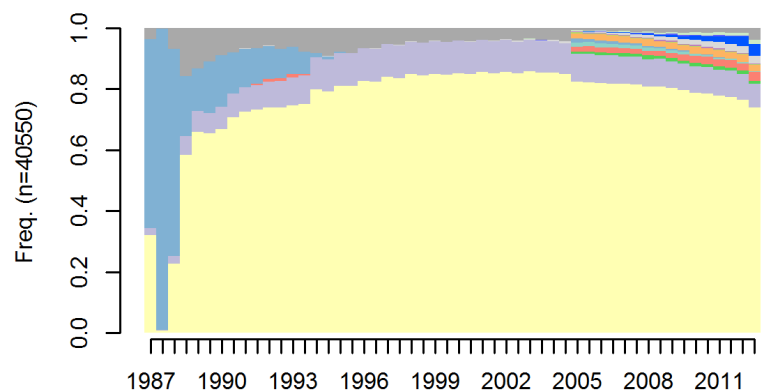

M3. Long gap in labour market activity (5.3\%)

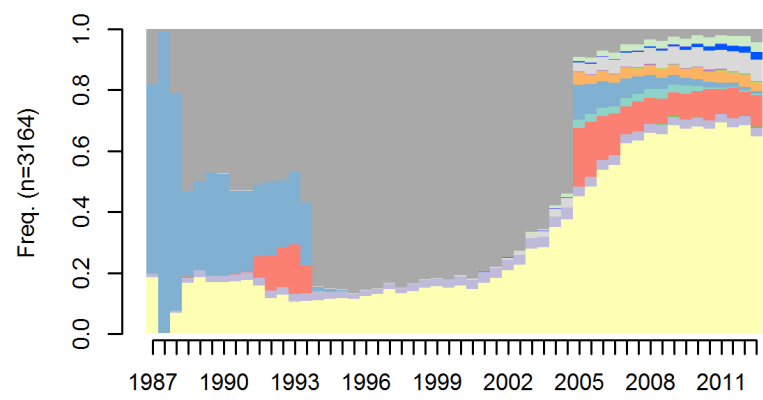

M5. Disability pension (2.5\%)

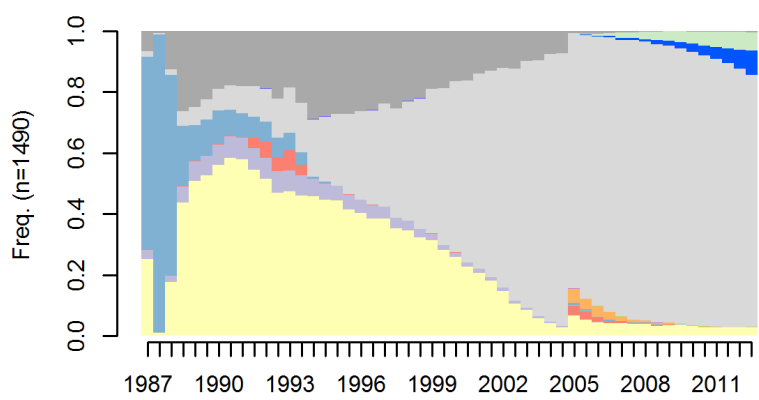

M7. Deceased (1.2\%)

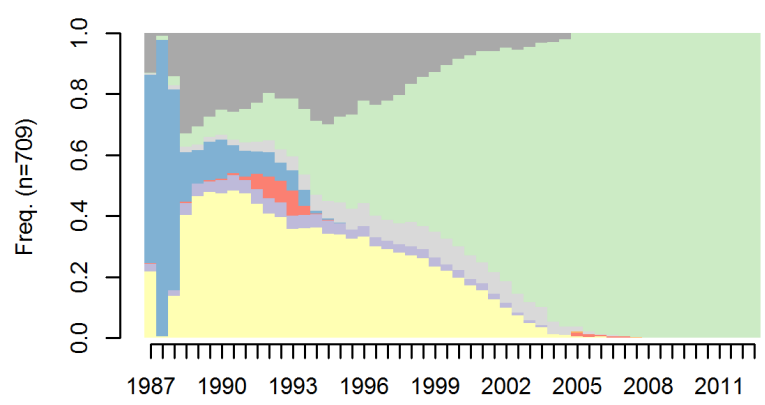

M2. Outside of labour market in the 1990s (16.7\%)

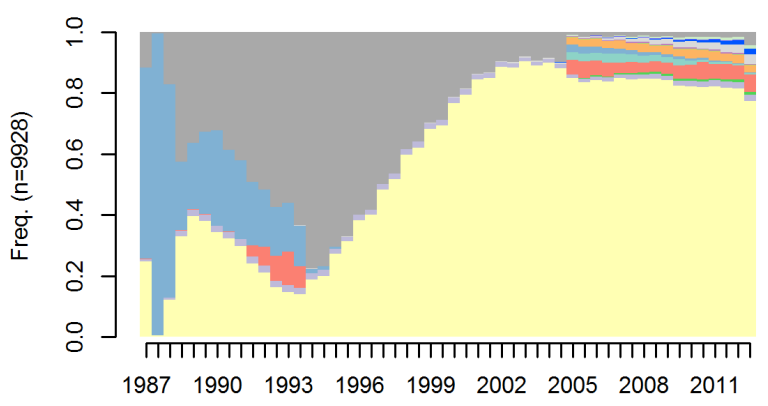

M4. Unemployed throughout $(2.6 \%)$

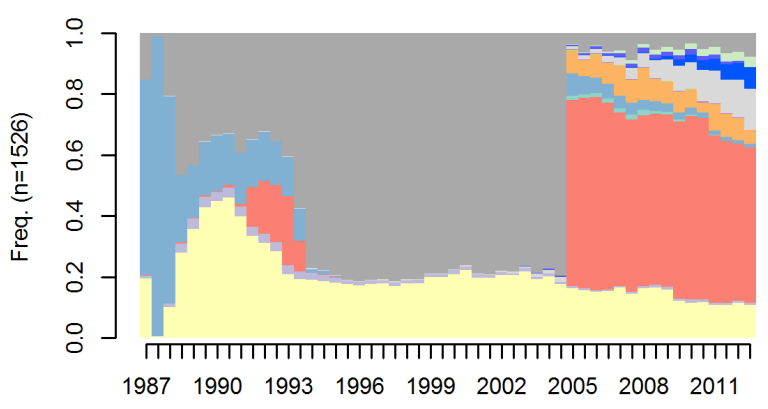

M6. Not much or no data $(3.5 \%)$

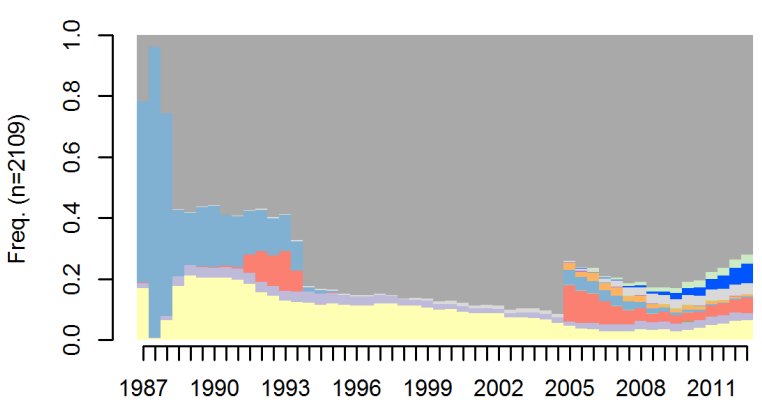

Figure 2. State distribution plot of mothers' clusters. Parents' data on other than on employment, pensions and deaths are missing between 1994 and 2004 

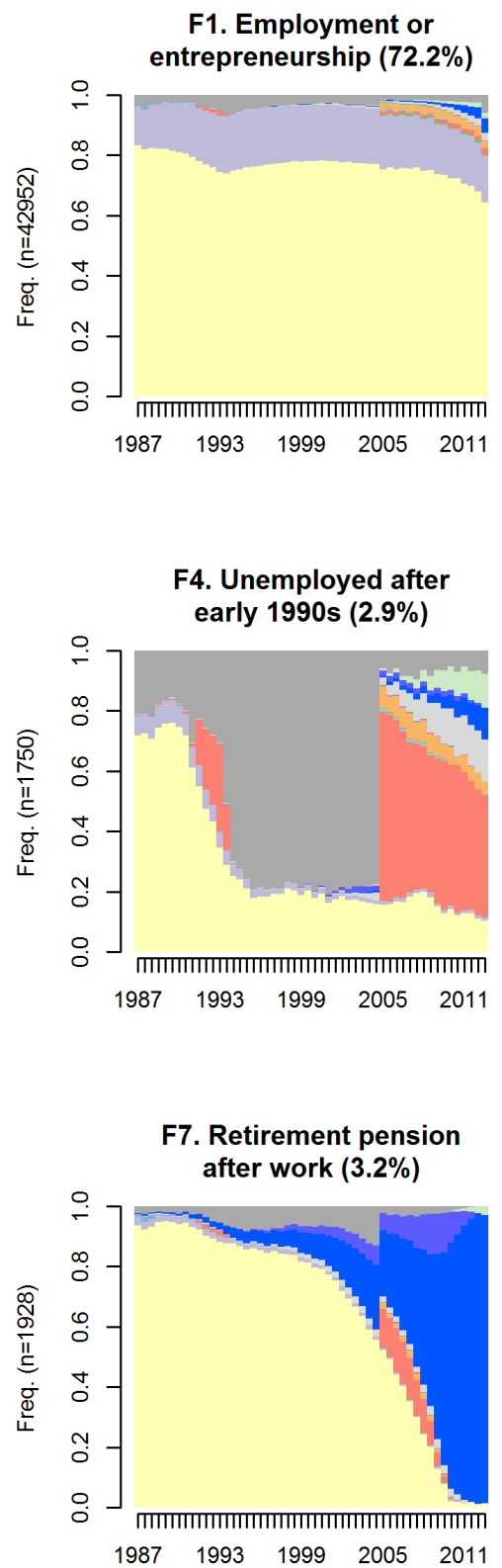

F10. Late death $(2.3 \%)$

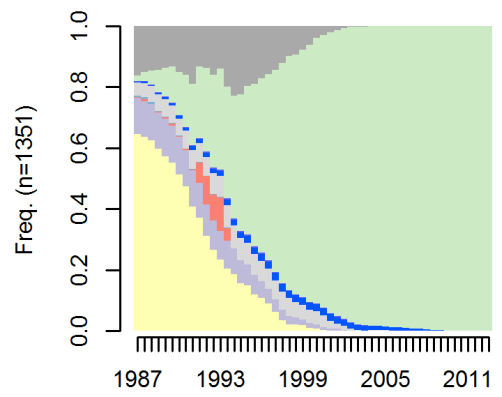

F2. Unemployed in the early $1990 \mathrm{~s}(4.3 \%)$

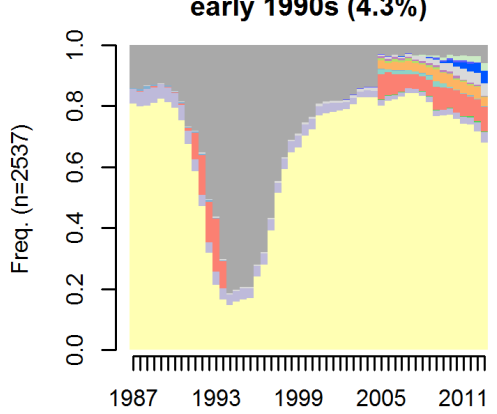

F5. Early disability pension $(2.7 \%)$

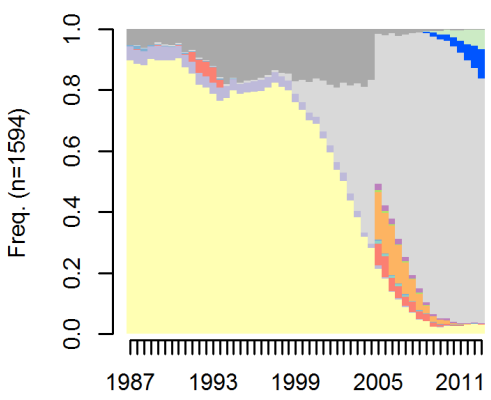

F8. Not much or no data (3.3\%)

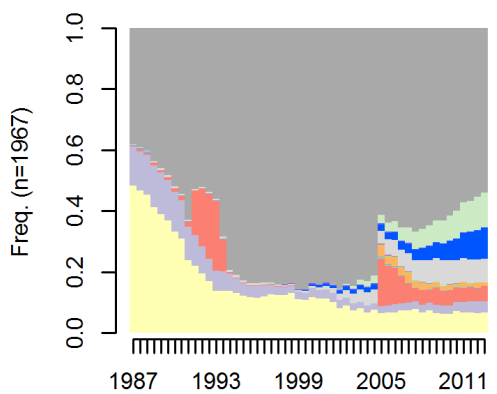

F3. Unemployed starting in 2009 (3.2\%)

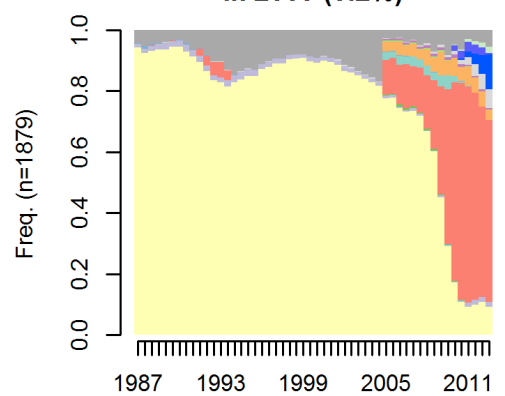

F6. Late disability pension $(2.5 \%)$

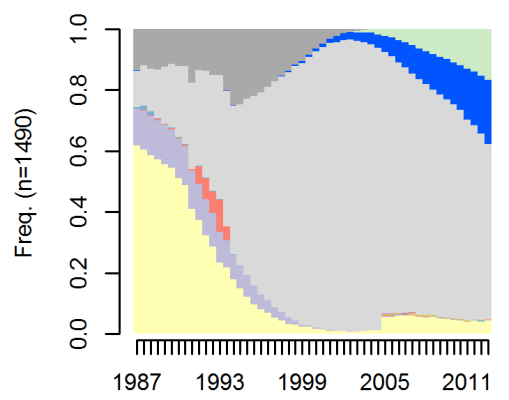

F9. Early death (2\%)

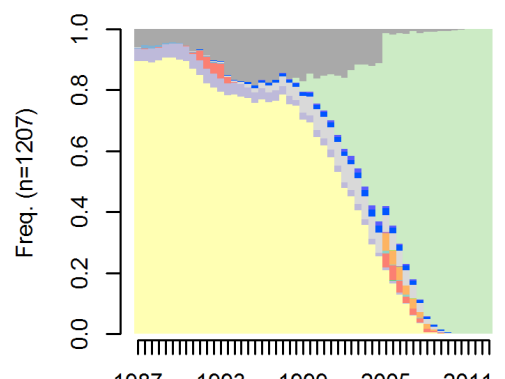

Figure 3. State distribution plot of fathers' clusters. Parents' data on other than employment, pensions and deaths are missing between 1994 and 2004 


\section{Regression results}

We found strong connections between the parents' and children's trajectories (Table 5). The connections remain even when we bring in strong background and predictor variables in regression models 2-4.

\section{Education and employment trajectories}

The reference cluster in the children's trajectory clusters is education. In clusters C2-C5, where we first have education with an upper-secondary-level study grant and subsequently three employment clusters, we can see the interplay between parental trajectories and having received an early study grant and also choosing employment over further education.

In both the upper-secondary-level study grant groups we see a strong connection to parents' divorce or parents never marrying. The study grant indicates a lower level of household income due to the upper secondary level benefit system in Finland; thus marriage between parents' links to a financially more secure youth.

In education cluster C2, parental employment trajectories show mostly highly significant connections with having received an uppersecondary-level study grant. We also see a strong connection to unmarried parents. Females take this path more often than males, but sex is not significant in the last model (model 4, male RRR $0.77,95 \% \mathrm{Cl}$ $[0.58,1.00])$. Of the parents' unemployment trajectories, longer inactivities have stronger connections than short inactivities. Father's early disability pension $\mathrm{F} 5$ has a stronger connection than F6, indicating late disability pension. For mothers, the relative risk ratio for any disability pension, M5, remains between these two, resulting possibly from an averaging out of the timing of disability pensions (one disability pension group vs. early and late). Interestingly, both mothers' and fathers' groups (M6 and F8) with no data show slightly weaker connections to the second child cluster than long inactivities, though still significant.

Parental employment trajectories do not show many significant connections to children being in employment over education in cluster C3. The lack of an early study grant indicates financially more stable youth, so other factors are at play here. The strongest connections are with male sex, average school grade, and parents' level of education. When we move on to employment cluster C4 (with a study grant), we see that the parental employment trajectory connections become significant, with a strong connection also to unmarried parents and parents with a low level of education, possibly indicating a low household income during youth resulting from a combination of these factors. Parents' low education level has a stronger connection to employment cluster C4 than to education cluster C2.

Employment cluster C5 (employment after difficulties) shows weaker but still significant connections to parents' trajectories. In this cluster the grouping is a result of a similar situation in the labour market during the 2008 recession and before. The connections to family background here might be more random.

If we now look at the transition from regression model 3 to model 4 , where we add the average school grade to the model, we see that the effect of parental education level in the regression model is weakened, much more so than is parental labour market inactivity. Some long periods of parental inactivity connections even become stronger in model 4. This indicates two things: First, parental level of education is a strong predictor of school achievement, and that works here by weakening the statistical connection between parental education level and their children's school achievement related trajectories. School achievement itself strongly predicts the children's trajectory, since uppersecondary-level vocational education most often implies lower comprehensive school achievement than general upper-secondary-level education. General upper-secondary-level education commonly leads to further education, while vocational school rarely does (though further education is at present possible) and instead leads to relatively early employment. Second, parental labour market inactivity trajectories are strong predictors of the children's trajectories regardless of other factors, and there is no strong correlation between the parents' employment trajectories and children's comprehensive school achievement.

What this means in real life is another matter. School achievement and aspirations have been shown to be a mediator of childhood circumstances (Bäckman \& Nilsson, 2011; Schoon, 2014). Here we see that parental employment trajectories have a strong effect regardless of school achievement and parental level of education (and other predictors), while parental education level more often works via children's school achievement. 


\section{Table 5. Regression results for models $1-4$. Relative risk ratios}

\begin{tabular}{|c|c|c|c|c|c|c|c|c|c|c|c|c|c|c|c|c|}
\hline & \multicolumn{4}{|c|}{ C2. Education with 2nd Ivl benefit } & \multicolumn{4}{|c|}{ C3. Employment } & \multicolumn{4}{|c|}{ C4. Employment with 2 nd Ivl benefit } & \multicolumn{4}{|c|}{ C5. Employment after difficulties } \\
\hline & 1 & 2 & 3 & $4^{1}$ & 1 & 2 & 3 & $4^{1}$ & 1 & 2 & 3 & $4^{1}$ & 1 & 2 & 3 & $4^{1}$ \\
\hline Mother (ref. Employment/entrepreneurship) & ref. & ref. & ref. & ref. & ref. & ref. & ref. & ref. & ref. & ref. & ref. & ref. & ref. & ref. & ref. & ref. \\
\hline M2. Outside of labour market in the 1990s & $1.42^{* * *}$ & $1.36^{* * *}$ & $1.32^{* * *}$ & $1.3^{* *}$ & $1.28^{* * *}$ & $1.21^{* * *}$ & $1.2^{* * *}$ & 1.13 & $1.63^{* * *}$ & $1.49^{* * *}$ & $1.42^{* * *}$ & $1.32^{* * *}$ & $1.48^{* * *}$ & $1.4^{* * *}$ & $1.38^{* * *}$ & $1.3^{* *}$ \\
\hline M3. Long gap in labour market activity & $3.23^{* * *}$ & $2.94^{* * *}$ & $3.26^{* * *}$ & $3.54^{* * *}$ & $1.65^{* * *}$ & $1.4^{* * *}$ & $1.4^{* * *}$ & $1.39 * * *$ & $4.45^{* * *}$ & $3.56^{* * *}$ & $3.75^{* * *}$ & $3.69^{* * *}$ & $3.37^{* * *}$ & $2.91^{* * *}$ & $2.98^{* * *}$ & $3^{* * *}$ \\
\hline M4. Unemployed throughout & $4.98^{* * *}$ & $3.9 * * *$ & $2.89 * * *$ & $3.35^{* * *}$ & $2.18^{* * *}$ & $1.48^{* *}$ & 1.22 & 1.2 & $7.27^{* * *}$ & $4.53^{* * *}$ & $3.1^{* * *}$ & $3.03^{* * *}$ & $4.56^{* * *}$ & $3.2^{* * *}$ & $2.4^{* * *}$ & $2.43^{* * *}$ \\
\hline M5. Disability pension & $3.25^{* * *}$ & $2.7^{* * *}$ & $2.4^{* * *}$ & $2.38^{* * *}$ & $1.39^{* *}$ & 1.03 & 0.97 & 0.96 & $3.83^{* * *}$ & $2.67^{* * *}$ & $2.33^{* * *}$ & $2.32^{* * *}$ & $2.5^{* * *}$ & $1.9^{* * *}$ & $1.73^{* * *}$ & $1.68^{* * *}$ \\
\hline M6. Not much or no data & $1.59^{* * *}$ & $1.6^{* * *}$ & $1.75^{* * *}$ & $1.92^{* * *}$ & $1.25^{*}$ & 1.15 & $1.2^{*}$ & $1.21^{* * *}$ & $1.72^{* * *}$ & $1.53^{* * *}$ & $1.74^{* * *}$ & $1.75^{* * *}$ & $1.55^{* *}$ & $1.44^{*}$ & $1.52^{* *}$ & $1.57^{* * *}$ \\
\hline M7. Deceased & $2.6^{* * *}$ & $2.57^{* * *}$ & 0.98 & 1.02 & 1.32 & 1.21 & 0.8 & 0.9 & $3.81^{* * *}$ & $3.43^{* * *}$ & 1.26 & $1.39^{* *}$ & $2.12^{* *}$ & $1.97^{* *}$ & 0.97 & 1.07 \\
\hline Father (ref. Employment/entrepreneurship) & ref. & ref. & ref. & ref. & ref. & ref. & ref. & ref. & ref. & ref. & ref. & ref. & ref. & ref. & ref. & ref. \\
\hline F2. Unemployed in the early $1990 \mathrm{~s}$ & $2.59 * * *$ & $2.42^{* * *}$ & $1.87^{* * *}$ & $1.9 * * *$ & $1.5^{* * *}$ & $1.35^{* * *}$ & $1.28^{* *}$ & $1.13^{* *}$ & $3.36^{* * *}$ & $2.93^{* * *}$ & $2.21^{* * *}$ & $1.93^{* * *}$ & $2.89 * * *$ & $2.63^{* * *}$ & $2.27^{* * *}$ & $2^{*}$ \\
\hline F3. Unemployed starting in 2009 & $1.84^{* * *}$ & $1.65^{* * *}$ & $1.33^{* * *}$ & $1.35^{*}$ & $1.33^{* * *}$ & 1.15 & 1.07 & 1.03 & $1.81^{* * *}$ & $1.49^{* * *}$ & 1.18 & 1.13 & $2.11^{* * *}$ & $1.85^{* * *}$ & $1.62^{* * *}$ & $1.54^{* * *}$ \\
\hline F4. Unemployed after early $1990 \mathrm{~s}$ & $7.21^{* * *}$ & $6.12^{* * *}$ & $3.38^{* * *}$ & $2.96^{* * *}$ & $2.22^{* * *}$ & $1.72^{* * *}$ & $1.43^{* *}$ & 1.05 & $10.43^{* * *}$ & $7.64^{* * *}$ & $4.09 * * *$ & $3.03^{* * *}$ & $7.51^{* * *}$ & $5.98^{* * *}$ & $4.03^{* * *}$ & $2.99 * * *$ \\
\hline F5. Early disability pension & $5.04^{* * *}$ & $4.18^{* * *}$ & $3.58^{* * *}$ & $3.66^{* * *}$ & $1.73^{* * *}$ & $1.29 *$ & 1.18 & $1.14^{*}$ & $5.42^{* * *}$ & $3.8^{* * *}$ & $3.08^{* * *}$ & $3.07^{* * *}$ & $3.59 * * *$ & $2.76^{* * *}$ & $2.4^{* * *}$ & $2.47^{* * *}$ \\
\hline F6. Late disability pension & $2.64^{* * *}$ & $2.26^{* * *}$ & $1.93^{* * *}$ & $1.81^{* * *}$ & $1.31^{* *}$ & 1.04 & 0.93 & $0.78^{*}$ & $3.37^{* * *}$ & $2.52^{* * *}$ & $2.08^{* * *}$ & $1.75^{* * *}$ & $3^{* * *}$ & $2.44^{* * *}$ & $2.13^{* * *}$ & $1.78^{* * *}$ \\
\hline F7. Retirement pension after work & 1.11 & 1.12 & $1.25^{* *}$ & $1.24^{* * *}$ & $0.89 *$ & 0.87 & 0.88 & 0.91 & 0.87 & 0.86 & 0.99 & 1.03 & 1.05 & 1.03 & 1.1 & 1.15 \\
\hline F8. Not much or no data & $3.92^{* * *}$ & $3.65^{* * *}$ & $2.32^{* * *}$ & $2.23^{* * *}$ & $1.45^{* * *}$ & $1.25^{*}$ & 1.17 & 0.92 & $3.93^{* * *}$ & $3.29 * * *$ & $2.11^{* * *}$ & $1.69^{* * *}$ & $3.48^{* * *}$ & $3.06^{* * *}$ & $2.34^{* * *}$ & $1.91^{* * *}$ \\
\hline F9. Early death & $5.72^{* * *}$ & $5.27^{* * *}$ & $1.78^{* * *}$ & $1.67^{* * *}$ & $1.85^{* * *}$ & $1.6^{* * *}$ & 1.04 & 0.92 & $6.95 * * *$ & $5.75^{* * *}$ & $1.82^{* * *}$ & $1.6^{* * *}$ & $3.71^{* * *}$ & $3.26^{* * *}$ & $1.49^{*}$ & $1.32^{* * *}$ \\
\hline F10. Late death & $3.76^{* * *}$ & $3.58^{* * *}$ & $1.22^{*}$ & 1.2 & $1.41^{* *}$ & $1.29 *$ & 0.88 & 0.86 & $4.19^{* * *}$ & $3.74^{* * *}$ & 1.22 & 1.19 & $3.21^{* * *}$ & $2.97^{* * *}$ & $1.42^{*}$ & $1.4^{*}$ \\
\hline F11. No registered father & $4.46^{* * *}$ & $3.31^{* * *}$ & 1.14 & 1.01 & $2.13^{* * *}$ & $1.29 *$ & 0.85 & 0.84 & $4.63^{* * *}$ & $2.62^{* * *}$ & 0.86 & 0.86 & $2.52^{* * *}$ & 1.6 & 0.74 & 0.72 \\
\hline Parents' education (ref. Higher academic level) & & ref. & ref. & ref. & & ref. & ref. & ref. & & ref. & ref. & ref. & & ref. & ref. & ref. \\
\hline Comprehensive level & & $3.58^{* * *}$ & $3.37^{* * *}$ & $3.32^{* * *}$ & & $9.21^{* * *}$ & $9.59^{* * *}$ & $4.27^{* * *}$ & & $16.13^{* * *}$ & $15.73^{* * *}$ & $7.46^{* * *}$ & & $6.95^{* * *}$ & $7.09 * * *$ & 3.37 \\
\hline Upper secondary level & & $3.54^{* * *}$ & $3.47^{* * *}$ & $3.42^{* * *}$ & & $5.46^{* * *}$ & $5.69^{* * *}$ & $3.01^{* * *}$ & & $11.39 * * *$ & $11.37^{* * *}$ & $6.27^{* * *}$ & & $4.39 * * *$ & $4.55^{* * *}$ & $2.54^{* * *}$ \\
\hline Lower academic level & & $2.05^{* * *}$ & $2.04^{* * *}$ & $1.99^{* * *}$ & & $2.39 * * *$ & $2.46^{* * *}$ & $1.76^{*}$ & & $3.34^{* * *}$ & $3.38^{* * *}$ & $2.5^{* * *}$ & & $2.04^{* * *}$ & $2.1^{* * *}$ & $1.52^{* * *}$ \\
\hline Parents' marriage (ref. Parents married) & & & ref. & ref. & & & ref. & ref. & & & ref. & ref. & & & ref. & ref. \\
\hline Parents not married & & & $5.42^{* * *}$ & $5.36^{* * *}$ & & & $1.76^{* * *}$ & $1.4^{* * *}$ & & & $6.58^{* * *}$ & $5.23^{* * *}$ & & & $3.01^{* * *}$ & ref. \\
\hline Sex (ref. Female) & & & ref. & ref. & & & ref. & ref. & & & ref. & ref. & & & ref. & \\
\hline Male & & & $0.78^{* * *}$ & 0.77 & & & $3.63^{* * *}$ & $1.79 * * *$ & & & $2.23^{* * *}$ & 1.16 & & & $2.65^{* * *}$ & $1.39 * *$ \\
\hline $\begin{array}{l}\text { Residence abroad at any time (r } \\
\text { abroad) }\end{array}$ & & & ref. & ref. & & & ref. & ref. & & & ref. & ref. & & & ref. & ref. \\
\hline Abroad at some point & & & 0.97 & 0.98 & & & $0.68^{* * *}$ & 0.92 & & & $0.36^{* * *}$ & $0.46^{* * *}$ & & & 0.92 & 1.21 \\
\hline Residence history not available & & & 1.25 & 1.21 & & & 1.48 & $2.2^{* * *}$ & & & 1.43 & $1.98^{* * *}$ & & & $3.59^{* * *}$ & $4.62^{* * *}$ \\
\hline Average grade at the end of comp. school & & & & 0.91 & & & & $0.22^{* * *}$ & & & & $0.25^{* * *}$ & & & & $0.26^{* * *}$ \\
\hline
\end{tabular}

${ }^{*} \mathrm{p}<0.05,{ }^{* *} \mathrm{p}<0.01,{ }^{* * *} \mathrm{p}<0.001 .^{1}=$ pooled results due to the multiple imputations. 


\section{Table 5. Regression results for models $1-4$ continued. Relative risk ratios}

\begin{tabular}{|c|c|c|c|c|c|c|c|c|c|c|c|c|c|c|c|c|}
\hline & \multicolumn{4}{|c|}{ C6. Early child care } & \multicolumn{4}{|c|}{ C7. Late child care } & \multicolumn{4}{|c|}{ C8. Frag. unemp. / emp } & \multicolumn{4}{|c|}{ C9. Frag. unemp. / social ass. } \\
\hline & 1 & 2 & 3 & $4^{1}$ & 1 & 2 & 3 & $4^{1}$ & 1 & 2 & 3 & $4^{1}$ & 1 & 2 & 3 & $4^{1}$ \\
\hline Mother (ref. Employment/entrepreneurship) & ref. & ref. & ref. & ref. & ref. & ref. & ref. & ref. & ref. & ref. & ref. & ref. & ref. & ref. & ref. & ref. \\
\hline M2. Outside of labour market in the $1990 \mathrm{~s}$ & $2.40^{* * *}$ & $2.21^{* * *}$ & $2.16^{* * *}$ & $1.9^{* * *}$ & $1.71^{* * *}$ & $1.61^{* * *}$ & $1.58^{* * *}$ & $1.5^{* * *}$ & $2.23^{* * *}$ & $2.03^{* * *}$ & $1.93^{* * *}$ & $1.72^{* * *}$ & $2.12^{* * *}$ & $1.94^{* * *}$ & $1.85^{* * *}$ & $1.66^{* * *}$ \\
\hline M3. Long gap in labour market activity & $7.60^{* * *}$ & $6.03^{* * *}$ & $7.07^{* * *}$ & $6.44^{* * *}$ & $3.07^{* * *}$ & $2.6^{* * *}$ & $2.93^{* * *}$ & $2.97^{* * *}$ & $8.44^{* * *}$ & $6.67^{* * *}$ & $6.91^{* * *}$ & $6.34^{* * *}$ & $6.95^{* * *}$ & $5.48^{* * *}$ & $5.67^{* * *}$ & $5.07 * * *$ \\
\hline M4. Unemployed throughout & $12.29 * * *$ & $7.45^{* * *}$ & $6.28^{* * *}$ & $5.59 * * *$ & $4.72^{* * *}$ & $3.22^{* * *}$ & $2.82^{* * *}$ & $2.82^{* * *}$ & $13.96 * * *$ & $8.52^{* * *}$ & $5.77^{* * *}$ & $5.47^{* * *}$ & $18.32^{* * *}$ & $11.05^{* * *}$ & $7.7^{* * *}$ & $6.94 * * *$ \\
\hline M5. Disability pension & $3.53^{* * *}$ & $2.40^{* * *}$ & $2.16^{* * *}$ & $2.11^{* * *}$ & $2.64^{* * *}$ & $1.97^{* * *}$ & $1.84^{* * *}$ & $1.84^{* * *}$ & $4.91 * * *$ & $3.35^{* * *}$ & $2.93^{* * *}$ & $2.78^{* * *}$ & $6.03 * * *$ & $4.08 * * *$ & $3.6^{* * *}$ & $3.46^{* * *}$ \\
\hline M6. Not much or no data & $3.37^{* * *}$ & $2.88^{* * *}$ & $3.39 * * *$ & $3.15^{* * *}$ & $1.46^{* * *}$ & $1.34^{*}$ & $1.55^{* *}$ & $1.62^{* * *}$ & $3.77^{* * *}$ & $3.25^{*}$ & $3.68^{* * *}$ & $3.56^{* * *}$ & $4.82^{* * *}$ & $4.09 * * *$ & $4.45^{* * *}$ & $4.14 * * *$ \\
\hline M7. Deceased & $2.80^{* * *}$ & $2.42^{* * *}$ & 1.03 & 1.13 & $1.81^{* * *}$ & $1.66^{*}$ & 0.85 & 0.89 & $4.19^{* * *}$ & $3.66^{*}$ & 1.35 & $1.46^{*}$ & $3.58^{* * *}$ & $3.07^{* * *}$ & 1.2 & $1.38^{* * *}$ \\
\hline Father (ref. Employment/entrepreneurship) & ref. & ref. & ref. & ref. & ref. & ref. & ref. & ref. & ref. & ref. & ref. & ref. & ref. & ref. & ref. & ref. \\
\hline F2. Unemployed in the early 1990s & $2.82^{* * *}$ & $2.43^{* * *}$ & $2.01^{* * *}$ & $1.69 * * *$ & $2.56^{* * *}$ & $2.3^{* * *}$ & $2.01^{* * *}$ & $1.82^{*}$ & $6.29 * * *$ & $5.43^{* * *}$ & $4.01^{* * *}$ & $3.18^{* * *}$ & $4.95^{* * *}$ & $4.25^{* * *}$ & $3.28^{* * *}$ & $2.56^{* * *}$ \\
\hline F3. Unemployed starting in 2009 & $1.80^{* * *}$ & $1.49^{* * *}$ & $1.24 *$ & 1.18 & $1.59^{* * *}$ & $1.38 * *$ & 1.22 & 1.2 & $4^{* * *}$ & $3.28^{* *}$ & $2.6^{* * *}$ & $2.23^{* * *}$ & $2.74^{* * *}$ & $2.25^{* * *}$ & $1.83^{* * *}$ & $1.59 * * *$ \\
\hline F4. Unemployed after early $1990 \mathrm{~s}$ & $9.12^{* * *}$ & $6.55^{* * *}$ & $3.88^{* * *}$ & $2.78^{* * *}$ & $5.36^{* * *}$ & $4.19^{* * *}$ & $2.86^{* * *}$ & $2.23^{* * *}$ & $17.9^{* * *}$ & $12.95^{* * *}$ & $6.91^{* * *}$ & $4.63^{* * *}$ & $15.43^{* * *}$ & $11.09 * * *$ & $6.28^{* * *}$ & $4.17^{* * *}$ \\
\hline F5. Early disability pension & $4.33^{* * *}$ & $2.96^{* * *}$ & $2.80^{* * *}$ & $2.65^{* * *}$ & $2.84^{* * *}$ & $2.14^{* * *}$ & $2.05^{* * *}$ & $2.1^{* * *}$ & $10.59 * * *$ & $7.3^{* * *}$ & $5.74^{* * *}$ & $5.31^{* * *}$ & $6.05 * * *$ & $4.13^{* * *}$ & $3.36^{* * *}$ & $3.08^{* * *}$ \\
\hline F6. Late disability pension & $3.76^{* * *}$ & $2.78^{* * *}$ & $2.58^{* * *}$ & $2.03^{* * *}$ & $2.04^{* * *}$ & $1.63^{* * *}$ & $1.55^{* *}$ & 1.33 & $3.14 * * *$ & $2.32^{* * *}$ & $1.88^{* *}$ & 1.46 & $4.07^{* * *}$ & $3.01^{* * *}$ & $2.52^{* * *}$ & $1.9 * * *$ \\
\hline F7. Retirement pension after work & 0.79 & 0.76 & 0.84 & 0.90 & $0.70^{* * *}$ & $0.69^{* *}$ & $0.73^{*}$ & 0.75 & 1.35 & 1.32 & $1.54^{*}$ & $1.47^{* * *}$ & 0.93 & 0.89 & 1.01 & 1.11 \\
\hline F8. Not much or no data & $4.83^{* * *}$ & $3.90 * * *$ & $2.81^{* * *}$ & $2.08^{* * *}$ & $2.89^{* * *}$ & $2.5^{* * *}$ & $1.98^{* * *}$ & $1.71^{* * *}$ & $7.48^{* * *}$ & $6.15^{* * *}$ & $3.87^{* * *}$ & $2.8^{* * *}$ & $9.91^{* * *}$ & $8.02^{* * *}$ & $5.24^{* * *}$ & $3.58^{* * *}$ \\
\hline F9. Early death & $4.58^{* * *}$ & $3.70^{* * *}$ & $1.45^{*}$ & $1.29 * * *$ & $3.51^{* * *}$ & $3.04^{* * *}$ & $1.5^{*}$ & $1.37^{* * *}$ & $10.44 * * *$ & $8.51^{* * *}$ & $2.6^{* * *}$ & $2.09 * * *$ & $7.71^{* * *}$ & $6.2^{* * *}$ & $2.1^{* * *}$ & $1.68^{* * *}$ \\
\hline F10. Late death & $2.77^{* * *}$ & $2.45^{* * *}$ & 0.93 & 0.95 & $2.85^{* * *}$ & $2.61^{* * *}$ & 1.26 & 1.26 & $6.52^{* * *}$ & $5.77^{* * *}$ & $1.85^{* * *}$ & $1.64^{*}$ & $4.06^{* * *}$ & $3.59^{* * *}$ & 1.27 & 1.18 \\
\hline F11. No registered father & $4.73^{* * *}$ & $2.49 * * *$ & 1.04 & 1.01 & $3.14^{* * *}$ & $1.94^{* *}$ & 1 & 0.99 & $7.84^{* * *}$ & $4.29 * *$ & 1.37 & 1.18 & $8.08^{* * *}$ & $4.28^{* * *}$ & 1.49 & 1.23 \\
\hline Parents' education (ref. Higher academic level) & & ref. & ref. & ref. & & ref. & ref. & ref. & & ref. & ref. & ref. & & ref. & ref. & ref. \\
\hline Comprehensive level & & $16.89 * * *$ & $14.54^{* * *}$ & $5.53^{* * *}$ & & $7.56^{* * *}$ & $6.82^{* * *}$ & $3.71^{* * *}$ & & $16.42^{* * *}$ & $16.05 * * *$ & $5.94 * * *$ & & $16.84^{* * *}$ & $16.63^{* * *}$ & $5.62^{* * *}$ \\
\hline Upper secondary level & & $8.68^{* * *}$ & $7.76^{* * *}$ & $3.46^{* * *}$ & & $4.78^{* * *}$ & $4.39 * * *$ & $2.7^{* * *}$ & & $10.06^{* * *}$ & $10.08^{* * *}$ & $4.33^{* * *}$ & & $8.96^{* * *}$ & $9.08^{* * *}$ & $3.77^{* * *}$ \\
\hline Lower academic level & & $2.54^{* * *}$ & $2.37^{* * *}$ & $1.56^{* * *}$ & & $1.9^{* * *}$ & $1.81^{* * *}$ & $1.38^{* * *}$ & & $2.8^{* * *}$ & $2.84^{* * *}$ & $1.81^{* * *}$ & & $2.55^{* * *}$ & $2.6^{* * *}$ & $1.63^{* *}$ \\
\hline Parents' marriage (ref. Parents married) & & & ref. & ref. & & & ref. & ref. & & & ref. & ref. & & & ref. & ref. \\
\hline Parents not married & & & $3.78^{* * *}$ & $2.78^{* * *}$ & & & $2.59^{* * *}$ & $2.16^{* * *}$ & & & $7.38^{* * *}$ & $5.18^{* * *}$ & & & $5.65^{* * *}$ & $4.01 * * *$ \\
\hline Sex (ref. Female) & & & ref. & ref. & & & ref. & ref. & & & ref. & ref. & & & ref. & ref. \\
\hline Male & & & $0.01 * * *$ & $0.03^{* * *}$ & & & $0.18^{* * *}$ & $0.13^{* * *}$ & & & $3.46^{* * *}$ & $1.57^{*}$ & & & $2.78^{* * *}$ & 1.17 \\
\hline $\begin{array}{l}\text { Residence abroad at any time (ref. Never } \\
\text { abroad) }\end{array}$ & & & ref. & ref. & & & ref. & ref. & & & ref. & ref. & & & ref. & ref. \\
\hline Abroad at some point & & & $0.47^{* * *}$ & $0.69^{* * *}$ & & & $0.43^{* * *}$ & $0.55^{*}$ & & & $0.48^{* *}$ & $0.68^{* * *}$ & & & 0.87 & 1.07 \\
\hline Residence history not available & & & $2.47^{*}$ & $2.89^{* * *}$ & & & $2.29 *$ & $2.62^{* * *}$ & & & 0.39 & 0.77 & & & 1.67 & $2.26^{* * *}$ \\
\hline Average grade at the end of comp. school & & & & $0.22 * * *$ & & & & $0.34^{* * *}$ & & & & $0.21 * * *$ & & & & $0.16^{* * *}$ \\
\hline
\end{tabular}

${ }^{*} p<0.05,{ }^{* *} p<0.01,{ }^{* * *} p<0.001 .^{1}=$ pooled results due to the multiple imputations. 


\section{Table 5. Regression results for models 1-4 continued. Relative risk ratios}

\begin{tabular}{|c|c|c|c|c|c|c|c|c|}
\hline & \multicolumn{4}{|c|}{ C10. Frag. no data / edu. / empl. } & \multicolumn{4}{|c|}{ C11. Not much or no data } \\
\hline & 1 & 2 & 3 & $4^{1}$ & 1 & 2 & 3 & $4^{1}$ \\
\hline Mother (ref. Employment/entrepreneurship) & ref. & ref. & ref. & ref. & ref. & ref. & ref. & ref. \\
\hline M2. Outside of labour market in the $1990 \mathrm{~s}$ & $1.46^{* * *}$ & $1.42^{* * *}$ & $1.41^{* * *}$ & $1.36^{* * *}$ & $1.37^{* * *}$ & $1.31^{* * *}$ & $1.28 * *$ & $1.21 * *$ \\
\hline M3. Long gap in labour market activity & $2.75^{* * *}$ & $2.54^{* * *}$ & $2.55^{* * *}$ & $2.61^{* * *}$ & $3.8^{* * *}$ & $3.42^{* * *}$ & $3.39 * * *$ & $3.4^{* * *}$ \\
\hline M4. Unemployed throughout & $4.66^{* * *}$ & $3.82^{* * *}$ & $3.15^{* * *}$ & $3.3^{* * *}$ & $7.83^{* * *}$ & $5.97^{* * *}$ & $4.5^{* * *}$ & $4.3^{* * *}$ \\
\hline M5. Disability pension & $2.36^{* * *}$ & $2.04^{* * *}$ & $1.9^{* * *}$ & $1.92^{*}$ & $3.89 * * *$ & $3.17^{* * *}$ & $2.83^{* * *}$ & $2.7 * * *$ \\
\hline M6. Not much data available & $2.26^{* * *}$ & $2.18^{* * *}$ & $1.98^{* * *}$ & $2.09^{* * *}$ & $10.89^{* * *}$ & $10.4^{* * *}$ & $7.45^{* * *}$ & $7.01^{* * *}$ \\
\hline M7. Deceased & $2.31^{* * *}$ & $2.25^{* * *}$ & 1.39 & $1.54^{* * *}$ & $2.73^{* * *}$ & $2.62^{* * *}$ & 1.34 & $1.56^{* * *}$ \\
\hline \multicolumn{9}{|l|}{ Father (ref. Employment/entrepreneurship) } \\
\hline F2. Unemployed in the early 1990s & $2.2^{* * *}$ & $2.11^{* * *}$ & $1.93^{* * *}$ & $1.79 * *$ & $2.64^{* * *}$ & $2.48^{* * *}$ & $2.1^{* * *}$ & $1.77^{* * *}$ \\
\hline F3. Unemployed starting in 2009 & 1.24 & 1.16 & 1.09 & 1.06 & $1.71^{* * *}$ & $1.56^{* *}$ & $1.42^{*}$ & 1.32 \\
\hline F4. Unemployed after early 1990 s & $4.73^{* * *}$ & $4.19^{* * *}$ & $3.28^{* * *}$ & $2.57^{* *}$ & $6.77^{* * *}$ & $5.74^{* * *}$ & $4^{* * *}$ & $2.88^{* * *}$ \\
\hline F5. Early disability pension & $2.44^{* * *}$ & $2.13^{* * *}$ & $1.97^{* * *}$ & $2.04^{* * *}$ & $4.73^{* * *}$ & $3.91^{* * *}$ & $3.45^{* * *}$ & $3.38^{* * *}$ \\
\hline F6. Late disability pension & $1.74^{* * *}$ & $1.56^{* * *}$ & $1.43^{* *}$ & $1.27^{* * *}$ & $2.18^{* * *}$ & $1.87^{* * *}$ & $1.67^{* *}$ & $1.36^{* * *}$ \\
\hline F7. Retirement pension after work & 1.02 & 1.01 & 1.05 & 1.07 & $1.29 *$ & 1.28 & $1.42 * *$ & $1.46^{* *}$ \\
\hline F8. Not much or no data & $2.64^{* * *}$ & $2.47^{* * *}$ & $1.9^{* * *}$ & $1.63^{* * *}$ & $9.73^{* * *}$ & $8.87^{* * *}$ & $4.8^{* * *}$ & $3.49 * * *$ \\
\hline F9. Early death & $3.75^{* * *}$ & $3.54^{* * *}$ & $2.16^{* * *}$ & 1.97 & $4.76^{* * *}$ & $4.39 * * *$ & $2.2 * * *$ & $1.87^{* * *}$ \\
\hline F10. Late death & $2.05^{* * *}$ & $1.97^{* * *}$ & 1.24 & 1.23 & $2.66^{* * *}$ & $2.52^{* * *}$ & 1.26 & 1.26 \\
\hline F11. No registered father & $2.54^{* * *}$ & $1.97^{* * *}$ & 1.14 & 1.05 & $10.3^{* * *}$ & $7.33^{* * *}$ & $2.74^{* * *}$ & $2.44 * * *$ \\
\hline \multicolumn{9}{|l|}{ Parents' education (ref. Higher academic level) } \\
\hline Comprehensive level & & $2.65^{* * *}$ & $2.81^{* * *}$ & $1.67 * *$ & & $3.91 * * *$ & $4.55^{* * *}$ & $2.02^{* * *}$ \\
\hline Upper secondary level & & $2.04^{* * *}$ & $2.21^{* * *}$ & $1.47 * *$ & & $2.82^{* * *}$ & $3.42^{* * *}$ & $1.8^{* *}$ \\
\hline Lower academic level & & $1.17^{* *}$ & $1.23^{* * *}$ & 0.97 & & $1.47^{* * *}$ & $1.62^{* * *}$ & $1.16^{* * *}$ \\
\hline \multicolumn{9}{|l|}{ Parents' marriage (ref. Parents married) } \\
\hline Parents not married & & & $1.91^{* * *}$ & $1.67^{* * *}$ & & & $2.74^{* * *}$ & $2.18^{* * *}$ \\
\hline \multicolumn{9}{|l|}{ Sex (ref. Female) } \\
\hline Male & & & $1.83^{* * *}$ & $1.18^{* * *}$ & & & $2.33^{* * *}$ & $1.14^{*}$ \\
\hline \multicolumn{9}{|l|}{$\begin{array}{l}\text { Residence abroad at any time (ref. Never } \\
\text { abroad) }\end{array}$} \\
\hline Abroad at some point & & & $2.41^{* * *}$ & $2.87^{* * *}$ & & & $5.35 * * *$ & $6.77^{* * *}$ \\
\hline Residence history not available & & & 1.55 & $1.81^{* * *}$ & & & 1.38 & $1.81^{* *}$ \\
\hline Average grade at the end of comp. school & & & & 0.38 & & & & $0.21 * * *$ \\
\hline
\end{tabular}

${ }^{*} p<0.05,{ }^{* *} p<0.01,{ }^{* * *} p<0.001 .{ }^{1}=$ pooled results due to the multiple imputations. 


\section{Child care trajectories}

Next, we have two child care trajectories. In the early child care trajectory (cluster C6), almost all recipients (model 4, male RRR $0.027,95 \% \mathrm{Cl}[0.020$, $0.036]$ ) of child care benefits relatively early in their early twenties are female. In cluster $\mathrm{C} 7$, child care starts a few years later, so is still relatively early, after a period of education or employment (model 4, male RRR $0.12,95 \% \mathrm{Cl}[0.096,0.170])$. The difference between these two is clear with respect to the connections to the parental trajectories. Long parental labour market inactivities and lower levels of parental education have stronger connections to child care at an early age than to later child care. Higher school grade and residence abroad at any time are strong protective measures in both clusters. Mothers' long labour market inactivities have a much stronger connection to early child care than those of fathers'. Of the mothers' clusters, the long gap (cluster M3) has the strongest connection (RRR 6.44, 95\% Cl [5.99, 6.91]), stronger than the next cluster $M 4$ with continuous unemployment (RRR 5.59, 95\% Cl [4.24, 7.38]). The difference between these two mothers' clusters is that in the former, some mothers have been on a very long child care career, which might, in some circumstances, encourage their daughters to bear children early.

Females have a strong majority in the child care clusters. Of the early child care cluster, $99 \%$ are female, and in the late child care cluster $87 \%$ are female.

When we move from model 3 to 4 , we are again seeing that adding the school grade weakens the effect of parental level of education, but at times even increases the effect of parental employment trajectories.

\section{Unemployment trajectories}

Parental trajectories that are characterised by long labour market inactivities, have their strongest connections to the children's unemployment trajectories in clusters $\mathrm{C} 8$ and $\mathrm{C9}$. The difference between these two outcomes is that in the former (C8) unemployment varies with employment, while in the latter (C9), unemployment varies with social assistance. In these two trajectories, we also have the strongest protective effect of higher average school grade (model 4 RRRs 0.21 and 0.16 , with $95 \% \mathrm{Cls}[0.18,0.23]$ and $[0.14,0.19]$, respectively). In cluster C9 the crude relative risk ratios of the longest labour market inactivities of mothers (M4) and fathers (F4) in model 1 are at 18 and 15 respectively, and are gradually brought down to 7 and 4 in model 4 by other variables. Again long parental inactivities have stronger connections than shorter periods of absence.

Associations vary between mothers' two clusters with long inactivities (clusters M3 and M4) and children's two unemployment clusters ( $\mathrm{C} 8$ and C9). In children's unemployment trajectory C9, with social assistance, the stronger connection is with mothers' continuous inactivity (M4), while the mothers' long gap (M3) has the stronger connection to children's unemployment / employment cluster C8. As can be seen in Figure 2, most mothers in cluster $\mathrm{M} 3$ are indeed employed during the children's period of study in 2005-2012, which might offer some assistance to their children, while mothers in cluster M4 are unemployed. Also mothers' no data trajectory (cluster M6) has strong connections to children's unemployment clusters ( $\mathrm{C} 8$ and $\mathrm{C} 9$ ).

Other strong predictors are parents' level of education and unmarried parents. Male sex is a highly significant predictor in model 3 , but loses most of its power in model 4 due to the addition of school achievement.

Adding school achievement in model 4 has the same effect that is present in other trajectory connections above: adding it strongly weakens the effect of a low level of parental education, but has a milder effect on parental employment trajectories. This again indicates that school achievement is a very strong predictor for these children's trajectories, and that it highly correlates with parental education level. Meanwhile, children's school achievement did not have an independent association with parental employment trajectories.

\section{No data}

Finally, we have the two clusters with various degrees of missing data (C10 and C11). Unlike in surveys, missing data can be meaningfully interpreted in many ways. We know that the children in cluster C11 are not in employment and not on unemployment benefit or any other benefit or pension. There might be some who are so well off that they do not need employment or any benefits, and some might be seriously excluded from society. Most likely, this group (cluster C11) is a mix of many things. We do see a statistically 
significant connection to most parental labour market trajectories with data and also to the trajectory of parents belonging to a no-data group, most likely due to childhood spent with family abroad. In C11, with most data missing, the share of expatriates is at $15 \%$ in 2005 and rises to $20 \%$ in 2012; while in $\mathrm{C} 10$ the proportion rises from less than $1 \%$ to $5 \%$ in $2005-2012$. Some $14 \%$ of young adults in $\mathrm{C} 11$ have resided abroad the entire study time, leaving their mark in some other country's registers, but not in Finnish ones.

Here for the first time in the regression models, in the no-data groups, residence abroad is a strong predictor (C10 and C11 in model 4 RRRs 2.87 and 6.77, 95\% Cls [2.07, 3.96] and [5.02, 9.14], respectively). The connection to not having a registered father is at its strongest in $\mathrm{C} 11$, with a possible link to unknown family connections abroad.

The children's cluster C10, where missing data interchanges with education or employment, the connection to parental trajectories with long labour market inactivities is relatively weak, but still highly significant in most cases. What is apparent is that there might be some other factors, unknown life events or circumstances, not present in the model that push children to this trajectory. This is also indicated by school achievement, which is a slightly less protective factor than in most of the other children's trajectories. This group is in part a mix of children on either education or employment trajectories, who cluster together due to gaps in their sequences, which could result from a wide variety of parental backgrounds, thus weakening the statistical connections. When taking a closer look, we see that some of the least common trajectories are clustered here, for instance, disability pensions.

\section{Discussion}

In this article, our first objective was to identify the most significant early adulthood trajectories in the Finnish Birth Cohort 1987, and the second objective was to identify their parents' most common employment trajectories during the lives of the birth cohort. We studied the early adulthood trajectories of children and their parents' employment trajectories using sequence analysis and cluster analysis. We identified 12 children's trajectories, or clusters, and 10 fathers' and 7 mothers' trajectories. More than two thirds of mothers (68\%) and fathers (72\%) have continuously been in employment, and we saw that the same proportion of children is on a stable education or employment trajectory (73\%). We are left with between a quarter and one-third of the population who are not on these trajectories.

In addition to the most common employment or education trajectories, we found that children were on less continuous or more disrupted education or employment trajectories, on early child care trajectories, unemployment trajectories or on a trajectory for which we do not have much data. Most NEET-type and missing data trajectories were very persistent during the study years. We did not find common unemployment trajectories in which the situation for the young adults improved over the eight years of study.

Some mothers have been outside of the labour market for a long while. The most common gap in labour market activity took place during the 1990s recession and in its aftermath. Following a gap, some $5 \%$ of mothers returned to the labour market only during the late 2000 s, with some $3 \%$ never entirely returning. The rest of the mothers were on disability pension, the no-data group, or deceased.

Likewise, fathers had long absences from the labour market. Some $7 \%$ of fathers suffered in the 1990 s recession, $3 \%$ never entirely returning to the labour market. The latest recession of 2008 took a toll on $3 \%$ of fathers, who mostly did not return to employment during this follow-up. More fathers than mothers were on disability pension, on old age pension or had died, so we saw fit to split groups based on the timing of pension or death, early and late. Similar to children and mothers, some of the fathers were in a no-data group.

Our third objective was to see how much children's early trajectories are affected by their parents' employment trajectories, and we used multinomial logistic regression to find connections between them. Generally, the results show that parents' long absences from the labour market have strong links to children's early child care, NEET-type and missing data paths.

Parents' labour market trajectories did not have many significant connections to children being on an employment trajectory rather than further education. Here other factors were at play: sex, parental education and comprehensive school achievement. On the other hand, parental trajectories characterised by long absences from 
the labour market were strongly linked to children's early employment trajectories that begin with a study grant. Thus, in circumstances of low family income the benefit system assists children in moving forward. Females are more strongly represented in clusters that receive early uppersecondary-level study grants, which could indicate that males are less prepared to use the benefit system.

When looking at the children's child care trajectories, family background distinguished those with very early and early child care. Those who were on the earlier child care trajectory had stronger links to childhood disadvantages than those on the later child care trajectory. Mothers' long labour market absences had strong connections to these trajectories, which were almost entirely female trajectories, while fathers' long absences from work had slightly weaker but mostly significant connections. Parents' low education and children's low comprehensive school achievement had strong connections to both trajectories. The strong link to mothers' late return to the labour market could indicate a connection between mother's long child care career and children's early child care.

As our investigation focused on transitions during early adulthood, it is not surprising that we did not identify major continuous unemployment trajectories for children. Instead we found two clusters in which unemployment interchanges with employment or with social assistance. In these two trajectories, we have the strongest connections to parents' long labour market absences. These clusters have a male majority, but we saw stronger connections to mothers' employment trajectories than to those of fathers. In Finland, mothers are more often lone parents than fathers (Official Statistics Finland: Families, 2015), but joint custodies are not registered.

Since we sequenced an entire birth cohort, we also had thousands of cases with not much or no data. In the Finnish context, with its strong reliance on registers, no data equals no employment, no entrepreneurship and no benefits, which might include people with other kinds of support, possibly support from family or a spouse, or at the other end, in a situation of serious exclusion from society. Given the presence of these groups, we included residence data in the regression model to see if there is a connection to residence abroad, which would explain the lack of register data. But while residence is a strong predictor, there are other strong factors. In the first child no-data group the connections to family background are relatively weak (and some statistically insignificant), resulting possibly from the group mix, which includes children from a wide variety of backgrounds. In the latter group, where data are almost entirely or entirely missing, we saw strong connections to parents' long labour market absences and also to the mothers' no-data group. Future research should try to identify the background selection processes leading to these cluster memberships. They may have something to do with somatic or mental health, substance abuse, or phenomena related to institutional arrangements.

Throughout the study, we saw that children's average comprehensive school grade is a strong predictor of their early adulthood trajectory. If grades are too low some education doors will be closed, which will in most cases result in an employment trajectory over further education. Very low grades are connected to disadvantages during early adulthood. We found that grades are strongly connected to parents' educational level, but the connections between parents' labour market activity and children's school grades are weak. Earlier evidence (Schoon, 2014) shows that parental unemployment can raise children's educational aspirations, as they might see value in education to avoid their parents' plight. On the other hand, parental unemployment trajectories could be discouraging. If parental worklessness has countervailing effects, we would expect a weakening of its relationship to child outcomes. Most children's trajectories vary by sex, which relates to school achievement difference between males and females. Could it be that males need more interventions during hardship than females during their years in school?

In Norway, fathers experiencing job loss had a stronger effect on children than mothers, possibly due to traditional role models at home (Rege, Telle \& Votruba, 2007). This was not true in the current Finnish study, where even though the subjects are nearly the same age as those in Rege et al.'s study (2007), mothers' trajectories had a stronger connection to disadvantageous male-dominated trajectories than those of fathers, and equally strong connection elsewhere. Female labour market participation in Finland has been at a high 
level throughout the lives of this cohort, so traditional roles may have weakened.

Overall parents' employment trajectories had very strong connections to children's early adulthood trajectories, at times stronger than parents' education, although the impact of parents' education is most likely funnelled through children's comprehensive school achievement. Especially parents' long absences from the labour market showed up as strong predictors of the more
NEET-typed and missing data trajectories of children.

By using sequence analysis and 52 data points with sampling, not cross-sectioning, from the entire length of the birth cohort's life, we obtained a good picture of parents' long periods of labour market exclusion. The excellent quality data allowed us to draw a picture of highly diverse early adult pathways and to identify the significant role that parental employment trajectories have upon them.

\section{Acknowledgements}

An earlier version of this paper was presented at The 8th Nordic Working Life Conference in Tampere, Finland, in October 2016. This study was supported by grants from the Academy of Finland strategic fund, The Finnish Work Environment Fund, Alli Paasikivi Foundation, Palkansaajasäätiö, and European Social Fund in project "Six City Strategy". The Finnish Birth Cohort 1987 study obtained a positive statement from the research ethical committee of the National Institute for Health and Welfare (Ethical committee \$28/2009), and permissions to use the register data was obtained from all register holding organisations.

\section{References}

Bäckman O. \& Nilsson A. (2011). Pathways to Social Exclusion - A Life-Course Study. European Sociological Review, 27(1), 107-123. https://doi.org/10.1093/esr/jcp064

Barone, C. \& Schizzerotto, A. (2011). INTRODUCTION: Career mobility, education, and intergenerational reproduction in five European Societies. European Societies, 13(3), 331-345. https://doi.org/10.1080/14616696.2011.568248

Brzinsky-Fay, C. (2007). Lost in Transition? Labour Market Entry Sequences of School Leavers in Europe. European Sociological Review, 23(4), 409-422. https://doi.org/10.1093/esr/jcm011

Brzinsky-Fay, C. (2011). School-to-work Transitions in International Comparison (Doctoral dissertation). Tampere, Finland: Tampere University Press.

Brzinsky-Fay, C. (2015). Gendered School-to-Work Transitions? A Sequence Approach to How Women and Men Enter the Labor market in Europe. In Blossfeld, H-P., Skopek, J., Triventi, M. \& Buchholz, S. (Eds.), Gender, Education and Employment - An Intergenerational Comparison of School-to-Work Transitions (pp. 39-61). Cheltenham, United Kingdom: Edward Elgar Publishing. https://doi.org/10.4337/9781784715038.00010

Brzinsky-Fay, C. \& Solga, H. (2016). Compressed, postponed, or disadvantaged? School-to-work-transition patterns and early occupational attainment in West Germany. Research In Social Stratification And Mobility, 46, Part A, 21-36. https://doi.org/10.1016/j.rssm.2016.01.004

Bukodi, E. \& Goldthorpe, J. H. (2011). Social class returns to higher education: chances of access to the professional and managerial salariat for men in three British birth cohorts. Longitudinal and Life Course Studies, 2(2), 185-201.

Caspi, A., Wright, B. R. E, Mofitt, T. E. \& Silva, P. A. (1998). Early Failure in the Labor Market: Childhood and Adolescent Predictors of Unemployment in the Transition to Adulthood. American Sociological Review, 63(3), 424-451. https://doi.org/10.2307/2657557

Cornwell, B. (2015). Social Sequence Analysis - Methods and Applications. Campridge, United Kingdom: Campridge University Press. https://doi.org/10.1017/CBO9781316212530 
Elder, G. H. Jr., Johnson, M. K. \& Crosnoe, R. (2003). The Emergence and Development of Life Course Theory. In Mortimer, J. T., Shanahan, M. J. (Eds.), Handbook of the Life Course (pp. 3-19). New York: Kluwer Academic/Plenum Publishers. https://doi.org/10.1007/978-0-306-48247-2_1

Gabadinho, A., Ritschard, G., Müller, N. S. \& Studer, M. (2011). Analyzing and Visualizing State Sequences in $\mathrm{R}$ with TraMineR. Journal of Statistical Software, 40(4), 1-37. https://doi.org/10.18637/jss.v040.i04

Gangl M. (2002). Changing labour markets and early career outcomes: labour market entry in Europe over the past decade. Work, employment and society. 16(1), 67-90. https://doi.org/10.1177/09500170222119254

Gray, M. \& Baxter, J. (2012). Family joblessness and child wellbeing in Australia. In Kalil, A., Haskins, R. \& Chesters, J. (Eds.), Investing in children: work, education, and social policy in two rich countries. Washington, DC: Brookings Institution.

Hollister, M. (2009). Is Optimal Matching Suboptimal? Sociological Methods \& Research, 38(2), 235-264. https://doi.org/10.1177/0049124109346164

Härkönen, J. \& Bihagen, E. (2011). Occupational Attainment and Career Progression in Sweden. European Societies, 13(3), 451-479. https://doi.org/10.1080/14616696.2011.568261

IImakunnas, I, Kauppinen, T. M. \& Kestilä, L. (2015). Sosioekonomisten syrjäytymisriskien kasautuminen vuonna 1977 syntyneillä nuorilla aikuisilla. Yhteiskuntapolitiikka, 80(3), 247-262.

Kangas, O. \& Saloniemi, A. (2013). Historical making, present and future challenges for the Nordic welfare state model in Finland. NordMod 2030, Sub-report 6.

Larja, L., Törmäkangas, T., Merikukka, M., Ristikari, T., Gissler, M. \& Paananen, R. (2016). NEET-indikaattori kuvaa nuorten syrjäytymistä. Tieto \& Trendi, 2/2016.

Mastekaasa, A. (2011). Social Origins and Labour Market Success - Stability and Change over Norwegian Birth Cohorts 1950-1969. European Sociological Review, 27(1), 1-15. https://doi.org/10.1093/esr/jcp050

McVicar, D. \& Anyadike-Danes, M. (2002). Predicting successful and unsuccessful transitions from school to work by using sequence methods. Journal of the Royal Statistical Society: Series A, 165(2), 317-334. https://doi.org/10.1111/1467-985X.00641

Mortimer J. T., Zhang L., Husseman J. \& Wu C (2014). Parental economic hardship and children's achievement orientations. Longitudinal and Life Course Studies, 5(2), 105-128. https://doi.org/10.14301/llcs.v5i2.271

Mroz T. A. \& Savage T. H. (2006). The Long-Term Effects of Youth Unemployment. The Journal of Human Resources, 41(2), 259-293. https://doi.org/10.3368/jhr.XLI.2.259

Müllner, D. (2013). fastcluster: Fast Hierarchical, Agglomerative Clustering Routines for R and Python. Journal of Statistical Software, 53(9), 1-18. https://doi.org/10.18637/jss.v053.i09

Official Statistics Finland: Families (2015). Helsinki: Statistics Finland. Accessed 22th June 2017 from http://www.stat.fi/til/perh/index_en.html

Official Statistics Finland: Labour Force Survey (2015). Helsinki: Statistics Finland. Accessed 22th June 2017 from http://www.stat.fi/til/tyti/index_en.html

Paananen, R. \& Gissler, M. (2012). Cohort profile: the 1987 Finnish Birth Cohort. International Journal of Epidemiology, 41(4), 941-945. https://doi.org/10.1093/ije/dyr035

R Core Team (2015). R: A language and environment for statistical computing (Version 3.2.3) [Software]. $R$ Foundation for Statistical Computing, Vienna, Austria. Available from https://www.R-project.org/

Rege, M., Telle, K. \& Votruba, M. (2007). Parental Job Loss and Children's School Performance. Discussion Papers No. 517, October 2007. Statistics Norway: Research Department.

Ristikari, T., Törmäkangas, L., Lappi, A., Haapakorva, P., Kiilakoski, T., Merikukka, M., Hautakoski, A., Pekkarinen, E. \& Gissler, M. (2016). Suomi nuorten kasvuympäristönä - 25 vuoden seuranta vuonna 1987 Suomessa syntyneistä nuorista aikuisista. THL Raportti 9/2016 / Nuorisotutkimusverkosto/Nuorisotutkimusseura, verkkojulkaisuja 101. Tampere, Finland: Juvenes Print. 
Sackmann, R. \& Wingens, M. (2003). From Transitions to Trajectories - Sequence Types. In Heinz, W. R. \& Marshall, V. W. (Eds.), Social Dynamics of the Life Course - Transitions, Institutions and Interrelations. New York, US: Aldine De Gruyter.

Schoon I. (2014). Parental worklessness and the experience of NEET among their offspring. Evidence from the Longitudinal Study of Young People in England (LSYPE). Longitudinal and Life Course Studies, 5(2), 129-150. https://doi.org/10.14301/llcs.v5i2.279

Schoon, I. \& Lyons-Amos, M. (2016). Diverse pathways in becoming an adult: The role of structure, agency and context. Research in Social Stratification and Mobility, 46, Part A, 11-20. https://doi.org/10.1016/j.rssm.2016.02.008

Sirniö, O., Kauppinen, T. M. \& Marttinen, P. (2016). Income trajectories after graduation: an intergenerational approach. Advances in Life Course Research, 30, 72-83. https://doi.org/10.1016/j.alcr.2016.04.001

Steijn, B., Need, A. \& Gesthuizen M. (2006). Well begun, half done? Long-term effects of labour market entry in the Netherlands, 1950-2000. Work, employment and society. 20(3), 453-472. https://doi.org/10.1177/0950017006066996

Studer, M. (2013). WeightedCluster Library Manual - A practical guide to creating typologies of trajectories in the social sciences with R. LIVES working papers, 24.

Van Buuren, S. \& Groothuis-Oudshoorn, K. (2011). mice: Multivariate Imputation by Chained Equations in R. Journal of Statistical Software, 45(3), 1-67. https://doi.org/10.18637/jss.v045.i03

Witting, M. \& Keski-Petäjä, M. (2016). Vanhempien koulutus vaikuttaa lasten valintoihin. Tieto \& Trendi, $2 / 2016$.

Zwysen, W. (2014). A disadvantaged childhood matters more if local unemployment is high. SOEPpapers on Multidisciplinary Panel Data Research, 725. https://doi.org/10.2139/ssrn.2547430 


\section{Appendix}

For the sequence analysis, we used TraMineR (Gabadinho, Ritschard, Müller \& Studer, 2011) on 64-bit R 3.2.3 (R Core Team, 2015) on a Windows computer. Distance and clustering methods were chosen due to the size of our data. For the distance method, we opted for hamming distances, which is, in short, optimal matching without insertion-deletion costs. This saved us several hours of computer time per run, but did not affect the cluster quality much if at all (Hollister, 2009). What insertion-deletion essentially does is allow the distance calculation to shift a sequence around on the time axle to match it with other sequences. By how much depends on the ratio of the insertion/deletion and substitution costs, where a lower ratio allows for a longer time shift. Too low an insertion/deletion cost interferes with substitution cost, however, since with a ratio below 0.5 , 'deletion+insertion' is a cheaper operation than a substitution. However, we are not concerned with the lack of insertions and deletions, since we consider the timing of the transitions as important.

For the clustering, we used the package 'fastcluster' (Müllner, 2013) in R. According to the package's author and our tests, it significantly speeds up hierarchical clustering with the Ward method, but offers the same results as other packages. Hierarchical clustering is nevertheless not always optimal (Studer, 2013), so we experimented with non-hierarchical partitioning around medoids (PAM) and also with a combination of these two, where the hierarchical clustering is given as an initial partitioning for the PAM method. For children's data, we found hierarchical clustering to be sufficient, while with PAM we discovered more interesting unemployment clusters for their parents.

With this data we discovered an internal limit to the number of individual sequences that the distance methods in TraMineR can handle (46,431 at the most), possibly due to internal limits in the size of R's 32-bit vector. Depending on the sequence complexity, one can try to reduce the number of identical sequences and go below the limit by means of the wcAggregateCases function in the R package WeightedCluster (Studer, 2013). We were able to process the data of both parents by aggregating the sequences (matching identical sequences and calculating distances only once per match), but in the children's more complex data, only 2,381 identical sequences were found from the original 59,476. As no other software packages for sequence analysis were available to us, we had to split the data and run two sequence analyses.

The children's distance and cluster analysis was split due to the split sequence data. We created a surplus of clusters from both parts, where mainly the largest resulting clusters formed several initial small clusters based on the time entering further education or employment. After forming the initial clusters, we joined the two data together. Since our objective was to find the most significant early adulthood trajectories with a focus on disadvantaged trajectories, we joined all the education and employment trajectory groups respectively by visual inspection (based on status distribution and timing), keeping early study benefit (which links to low income in the family) trajectories separate. This formed two large education and two large employment groups. All the other clusters were matched and joined to other clusters until a visual match could not be found. This resulted in our final cluster solution. Both parents' analyses were performed using the same principle but without the split: clusters were joined together until no match was found. Creating a surplus of clusters allowed us to find more interesting groups than was possible with fewer clusters.

The number of clusters has been debated at length and indicators for their quality also exist (Studer, 2013). We find that the quality indicators do not necessarily measure the usefulness of the clusters. We might, for example, discover clusters with both very low and very high within-sequence variances. A steady career, with low variance, is just as important to identify as a highly fragmented career, with high variance. The data also matter, since as the number of available labour market statuses and the length of the sequence grow, the variance necessarily grows as well. Large amounts of data and a high number of statuses might require more clusters. Usefulness depends on the research questions - here we want to identify the most significant trajectories. 